\title{
THE SINGLE SUPERVISION MECHANISM AND CONTAGION BETWEEN BANK AND
} SOVEREIGN RISK

\author{
María Cantero Sáiz* \\ (canterom@unican.es)/ Phone: +34 942203907 \\ Sergio Sanfilippo Azofra \\ (sanfilis@ unican.es) \\ Begoña Torre Olmo \\ (torreb@unican.es) \\ University of Cantabria \\ Avenida Los Castros s/n, 39005 Santander (Cantabria) \\ Spain
}

\section{ACKNOWLEDGEMENTS}

Funding: This work was supported by University of Cantabria Foundation for Education and Research in the Financial Sector (UCEIF Foundation).

${ }^{*}$ Corresponding author. 


\title{
THE SINGLE SUPERVISION MECHANISM AND CONTAGION BETWEEN BANK AND SOVEREIGN RISK
}

\begin{abstract}
The objective of this article is to analyse how the Single Supervision Mechanism (SSM), the first pillar of the European Banking Union, affects contagion between bank and sovereign risk in the eurozone. Additionally, we test whether this contagion is transmitted from banks to sovereigns or vice versa, and how this transmission differs before and after the SSM. On the one hand, using quarterly data from 80 banks and 13 eurozone countries over the period 2009-2016 (2,441 observations), we do not find solid evidence that the SSM reduces contagion from sovereign risk to banks' stock returns. On the other hand, the analysis of credit default swap (CDS) spreads comprises quarterly data from 25 banks and 10 eurozone countries between 2009 and 2016 (771 observations). We find that the announcement of the SSM in March 2013 reduces contagion between bank and sovereign CDS spreads. Additionally, before the announcement of the SSM, an increase in sovereign risk does not alter contagion. However, after this announcement, an increase in sovereign risk leads to lower contagion. Therefore, the announcement of the SSM has an immediate effect on CDS spreads, while there is not enough evidence for banks' stock returns.
\end{abstract}

Keywords: Single Supervision Mechanism, Bank risk, Sovereign risk, Contagion. JEL Classification: G01; G21; G28; H63.

\section{Introduction}

Since the onset of the financial crisis in 2008 , there has been a greater concern about sovereign and bank risk and the interdependencies between them. On the one hand, the weak capital and liquidity positions of the banking system, following the collapse of Lehman Brothers in September 2008, forced governments to rescue systemic banks. This raised national deficits to alarming levels, and hence the credit risk of the banking sector was transmitted to sovereigns (Alter and Schüler 2012; De Bruyckere et al. 2013). This situation was further aggravated, as the economic recession caused by the banking crisis forced governments to issue even more debt to stimulate economic activity (Barth et al. 2012). On the other hand, the financial crisis caused a sharp deterioration in the public finances of many European countries, raising investor concerns about sovereign risk. Greater sovereign risk was rapidly transmitted to the financial situation of the domestic banking sector, making it more risky and restricting its access to funding (Arezki et al. 2011; Correa et al. 2012; Cantero-Saiz et al. 2014). All of these facts heightened the interconnectedness between bank and sovereign risk, especially in peripheral countries, raising serious concerns about the stability of the global financial system.

In order to break this strong link between bank and sovereign risk, several initiatives were launched. The most ambitious was the proposal of the Banking Union by the European Commission in 2012, which consists of three pillars: the Single Supervision Mechanism (SSM), the Single Resolution Mechanism (SRM) and the common Deposit Guarantee Scheme (DGS). Among these pillars, the SSM was the first to become operational on 4 November 2014, when the European Central Bank (ECB) assumed responsibility for European banking supervision in collaboration with the National Supervisory Authorities (NSAs) of each country (European Commission 2012).

The SSM focuses on reducing contagion between banks and sovereigns, since its common regulatory framework will produce more homogeneous financial conditions across European banks, thereby making them less dependent on their home country's sovereign risk (Nowotny 2014). In addition, these common rules are also intended to enhance the robustness of the eurozone banking system and to provide financial assistance to banks if necessary, which will reduce risk spillovers from banks to sovereigns (Leblond 2014). However, the SSM also poses several issues, such as potential conflicting objectives between the ECB and the NSA, difficulties dealing with European countries that have not joined the SSM, conflicting relationships between micro- and macro-prudential supervision, or uncertainties about the ECB's ability to stabilize the banking system, since its main task is to ensure price stability (Angeloni 2015; Barba-Navaretti et al. 2015; Howarth and Quaglia 2015).

Despite the important repercussions that the SSM has on contagion between bank and sovereign risk, very little research has been done on this issue. On the one hand, the literature on contagion between bank and sovereign risk in Europe is relatively recent, since this was not a major concern until the current crisis (see, for example, Bolton and Jeanne 2011; Li and Zinna 2014; Bocola 2016; Altavilla et al. 2016; 
Buch et al. 2016). Some studies focus on the determinants of either bank or sovereign risk in isolation (Longstaff et al. 2011; Aizenman et al. 2013; Demirgüç-Kunt and Huizinga 2013; Gündüz and Kaya 2014). Other researchers focus on mutual contagion effects between sovereign and bank risk (Alter and Schüler 2012; De Bruyckere et al. 2013; Alter and Beyer 2014; Yu 2017). On the other hand, a few papers centre on the SSM, either from the perspective of its advantages and issues or that of its influence on the stock market, but do not quantify its effects on the stability of the financial system (Darvas and Wolff 2013; Leblond 2014; Barba-Navaretti et al. 2015; Howarth and Quaglia 2015; Carboni et al. 2017). Thus, to the best of our knowledge, there are no studies that analyse the effects of the SSM on contagion between bank and sovereign risk.

In this regard, this article provides two contributions to the existing literature. Firstly, we analyse how the adoption of the SSM affects contagion between bank and sovereign risk in the eurozone. Secondly, we are interested in determining whether this contagion is transmitted from banks to sovereigns or vice versa, and how this transmission differs before and after the SSM. So, we carry out two additional tests. On the one hand, we analyse how an increase in bank risk affects contagion both before and after the SSM, and on the other, we study how the impact of an increase in sovereign risk on this contagion varies before and after the SSM.

Our analysis is performed through two indicators: banks' stock returns and CDS spreads. On the one hand, the analysis of stock returns comprises quarterly data from 80 banks and 13 eurozone countries between 2009 and 2016 (2,441 observations). We do not obtain solid evidence that the SSM reduces contagion from sovereign risk to banks' stock returns. On the other hand, the analysis of CDS spreads is based on quarterly data from 25 banks and 10 eurozone countries over the period 2009-2016 (771 observations). We find that the announcement of the SSM in March 2013 reduces contagion between bank and sovereign CDS spreads. Additionally, before the announcement of the SSM, an increase in sovereign risk does not modify the degree of contagion, while after the announcement, an increase in sovereign risk leads to lower contagion, probably because after the announcement of the SSM, bank risk does not lead to an increase in sovereign risk, thereby reducing contagion between the two types of risk. The results of this article would suggest that CDS spreads respond immediately to the announcement of the SSM, while there is not consistent evidence for banks' stock prices.

The remainder of the paper is structured as follows: Section 2 reviews the previous literature; Section 3 focuses on empirical analysis and discussion of the results; and Section 4 presents the conclusions.

\section{Literature review}

\subsection{Contagion between bank and sovereign risk}

There are several mechanisms that explain the interconnectedness between bank and sovereign risk. On the one hand, greater sovereign risk can be transmitted to bank risk through several channels: asset holdings, collateral and government guarantees channels (CGFS 2011).

First, the asset holdings channel proposes that higher sovereign risk leads to losses in banks' government debt holdings, which impacts negatively on their balance sheets and makes them more of a risk (Correa et al. 2014). ${ }^{2}$ This mechanism is especially relevant in Europe, where banks are greatly exposed to their home country's debt (Breton et al. 2012). In addition, European banks are also exposed to nondomestic sovereign debt, thus the sustainability of public debt in stressed countries hinders the health of other eurozone countries' banking sectors (Bolton and Jeanne 2011; Li and Zinna 2014). In this regard, Angeloni and Wolff (2012) showed that banks' exposure to peripheral countries' debt reduces their stock market values. Popov and van Horen (2013) reported that European banks with higher exposure to foreign sovereign debt were more negatively affected during the sovereign debt crisis and reduced lending to a greater extent. Gennaioli et al. (2014), using a sample of both developed and emerging economies, found that the adverse effects of government defaults on credit supply are greater in countries where banks hold more government bonds. Similarly, Altavilla et al. (2016) revealed that banks' exposure to domestic debt in the eurozone stressed countries amplifies sovereign risk transmission on lending. On the other hand, Bocola (2016) and Buch et al. (2016) found that holdings of risky government bonds increase bank risk in Italy and Germany, respectively.

Second, the collateral channel states that greater sovereign risk reduces the collateral of banks to obtain funding and hence increases banks' risk (Davies and $\mathrm{Ng} \mathrm{2011).} \mathrm{Correa} \mathrm{et} \mathrm{al.} \mathrm{(2012)} \mathrm{showed} \mathrm{that}$ European banks were less able to obtain funding from the United States money market during the sovereign

\footnotetext{
${ }^{2}$ Banks usually hold domestic government debt, which enables them to hold less regulatory capital against that debt. This is because government securities have always been considered risk free (Barth et al. 2012).
} 
debt crisis due to collateral problems. De Bruyckere et al. (2013) reported evidence of a collateral channel for a sample of European banks, especially for those with poor levels of capital, a weak funding structure and less traditional banking activities. More recently, Engler and Steffen (2016), using a theoretical model calibrated to Greek data, also found support for the collateral channel.

Third, the government guarantees channel is related to the implicit and explicit guarantees that toobig-to-fail banks receive from their respective governments, due to the adverse effects that bankruptcy of such banks would have on the economy. Greater sovereign risk reduces the value of these guarantees, which contributes to increasing bank risk (Gray and Malone 2012). Brown and Dinc (2011), from a sample of emerging economies, reported that countries with higher deficit are less prone to rescue troubled banks. Schich and Lindh (2012) showed that the guarantees European banks obtain from governments become lower as the country's creditworthiness deteriorates. Similarly, Demirgüç-Kunt and Huizinga (2013) found that, during the crisis, systemic banks experienced a reduction in their market valuation in countries with large fiscal deficits, as these banks became too big to save. Correa et al. (2014) showed that greater sovereign risk has a negative impact on bank stock returns, especially for those banks that are expected to receive more government guarantees.

Apart from the previous three channels, other studies found that downgrades of sovereign rating are often followed by downgrades in domestic bank rating, which increases their risk. Arezki et al. (2011) focused on a sample of European countries over the period 2007-2010 and showed that sovereign rating downgrades caused an important spillover effect, both across financial markets and countries. Williams et al. (2013) documented that sovereign rating variations in emerging markets have a significant impact on bank rating. Alsakka et al. (2014) reported similar results in Europe, especially during the crisis and for the peripheral countries. Moreover, Caselli et al. (2014) found that sovereign rating downgrades have a negative effect on bank share prices in the eurozone, while rating upgrades have no influence. However, since sovereign risk impacts negatively on banks' balance sheets and reduces their government guarantees, it is likely that the reduction in banks' rating observed in these studies is more a consequence of the other three channels mentioned previously. Moreover, other studies suggested the existence of a sovereign ceiling, which implies that private sector ratings cannot be higher than sovereign ratings, and therefore in many cases this contagion effect from sovereign to bank risk could be automatic. This is because, normally, the private sector shows a high default dependence on its home country, as well as a low degree of insulation from the domestic economic and financial disruptions typically associated with sovereign distress. Borensztein et al. (2013) showed that the influence of a sovereign ceiling on corporate ratings is more pronounced in countries where there are still capital account restrictions and high political risk. More recently, Adelino and Ferreira (2016) found that banks with a rating equal to or above their sovereign prior to a downgrade are significantly more likely to be downgraded after a sovereign downgrade than banks rated below their sovereign.

On the other hand, higher bank risk can also be transmitted to sovereign risk. When bank risk sharply increases, governments should issue implicit or explicit guarantees to rescue troubled banks, especially if these banks are too big to fail. This raises public debt dramatically, which has a negative impact on public finances and leads to higher sovereign risk (Gray et al. 2008; Kräussl et al. 2016). In addition, banking crises imply economic recessions that weaken public finances and push up sovereign risk (Angeloni and Wolff 2012).

In this regard, Ejsing and Lemke (2011) reported that government bailouts and guarantee programmes for the financial sector induce a drop in bank risk but an increase in sovereign risk. Mody (2009) showed that the rescue of Bear Stearns in March 2008 raised spillovers from the banking to the sovereign sector, while Alter and Beyer (2014) obtained similar results for the nationalization of Bankia in Spain. Other papers revealed that government bailouts increase not only sovereign risk but also bank risk. For instance, Alter and Schüler (2012) showed evidence of risk contagion from banks to sovereigns, but only before bailout programmes are launched, while after these programmes, contagion is from sovereigns to banks. Similarly, Acharya et al. (2014) found that government bailouts seriously affect sovereign risk, which reduces the value of government guarantees that benefit the financial sector, and hence bank risk increases. Finally, other papers suggested that the effects of government bailouts on sovereign risk are determined by the size of the financial system. Gerlach et al. (2010) documented that sovereign risk increases with the size of the banking system in periods of crisis, especially following the implementation of government rescue packages. In addition, Dieckmann and Plank (2012) reported that the situation of a country's financial system affects sovereign risk, and the magnitude of this impact depends on the importance of a country's financial system in the pre-crisis years. 


\subsection{The Single Supervision Mechanism (SSM)}

As we mentioned previously, the financial crisis in Europe has led to greater contagion between bank and sovereign risk. To fight this observed contagion between banks and sovereigns, several policy reforms have been adopted. These reforms consider a macro-prudential approach to address systemic risk instead of focusing only on a micro-prudential perspective, which implies that regulation and supervision policies should also cover macroeconomic or sovereign aspects rather than individual financial institutions (Carboni et al. 2017). Examples of these macro-prudential reforms include the introduction of global liquidity standards, the new capital adequacy requirements under Basel III (which will enable banks to have more resources to protect themselves against the funding restrictions caused by sovereign risk) and the nonconventional measures carried out by the ECB to support the financing conditions of the banking sector and promote financial stability. ${ }^{3}$

One of the most ambitious macro-prudential measures to break the vicious circle between bank and sovereign risk has been the foundation of the European Banking Union in 2012, which is based on three pillars: the Single Supervision Mechanism (SSM), the Single Resolution Mechanism (SRM) and the common Deposit Guarantee Scheme (DGS). The first one, the SSM, became operational on 4 November 2014 and is the first pillar to officially come into force, since it is crucial to guarantee the functioning of the other two pillars. ${ }^{4}$ It grants the ECB a supervisory role to monitor all banks of the eurozone plus those of any non-eurozone countries wishing to join, in cooperation with the National Supervision Authorities (NSAs) (European Commission 2012). To ensure efficient supervision, the ECB only supervises directly significant credit institutions, ${ }^{5}$ while the remaining banks are supervised by their NSA. Before the SSM became operational in late 2014, several health checks of banks' balance sheets were performed to avoid damage to the SSM's reputation, due to troubled banks in the early days of its operation, so those banks that failed the test had to be recapitalized or restructured.

Several features of the SSM will contribute to reducing contagion between bank and sovereign risk (Leblond 2014; Nowotny 2014; Howarth and Quaglia 2015). First, this single supervision implies following clear and common rules, which will reduce the uncertainty premiums that some European banks pay. This will generate more homogeneous funding conditions for all banks, and hence the banking sector will be less dependent on its home country's sovereign risk. Second, the sharper supervision that the SSM promotes and the stress tests carried out before its adoption will improve the health of the banking system, thereby reducing the probability of economic recessions that can spill over to sovereign risk. Third, the SSM enables the direct intervention of the European Stability Mechanism (ESM). The ESM will provide temporary financial assistance to banks experiencing liquidity problems, which will mitigate credit risk transfer from banks to sovereigns, since governments will not need to rescue troubled banks with public debt.

Consequently, we propose that the SSM reduces contagion between bank and sovereign risk. This implies that the effects of an increase in bank (sovereign) risk on this contagion will differ before and after the implementation of the SSM. Prior to the implementation of the SSM, an increase in bank (sovereign) risk produces an increase in sovereign (bank) risk, which leads to greater contagion. However, after the SSM, bank (sovereign) risk does not sharply react to an increase in sovereign (bank) risk, thereby reducing contagion between both types of risk.

\section{Empirical analyses}

The analysis of SSM effects on contagion between bank and sovereign risk is divided into two empirical analyses. The first empirical analysis is based on stock returns indicators and the second on credit

\footnotetext{
3 These ECB non-conventional measures comprise the following key elements: fixed-rate full allotment for all refinancing operations, liquidity injections and longer-term credit operations, extension of collateral eligibility, currency swap agreements or several purchase programmes, such as the Covered Bond Purchase Programme (CBPP), the Asset-backed Securities Purchase Programme (ABSPP) and the Public Sector Purchase Programme (PSPP).

${ }^{4}$ The second pillar, the SRM, became fully operational on 1 January 2016, and its purpose is to ensure an orderly resolution of failing banks through a common resolution fund financed by the banking sector. The third pillar, the common DGS, is a system in each eurozone country that reimburses depositors (up to a defined limit) if their bank fails and deposits become unavailable. Member banks pay contributions to this guarantee scheme based on their risk profiles and other factors. In addition, the common DGS will improve the information that depositors receive and will reduce the time period to reimburse depositors up to seven working days by 2024 .

${ }^{5}$ The ECB started supervising the 126 significant banks of the participating countries, which hold almost $82 \%$ of banking assets in the eurozone. The ECB can decide at any time to classify a bank as significant to ensure that high supervisory standards are applied consistently.
} 
default swap (CDS) spread series. ${ }^{6}$ With regard to the first indicator, as shown by Figure 1, banks' stock prices decreased sharply in most of the eurozone countries during the first years of the financial crisis, especially in high sovereign risk countries (Greece, Ireland and Portugal). As regards the second indicator, Figures 2 and 3 show that both bank and sovereign CDS spreads increased strongly when the sovereign debt crisis was more intense (2010-2012), mainly in Greece, Ireland and Portugal. In the particular case of Greece, bank and sovereign CDS spreads remained particularly high in recent years, while in the rest of the eurozone countries these spreads were much more contained. Figure 4 depicts the correlation between bank and sovereign CDS spreads in several eurozone countries between 2009 and 2016. In general, there was an increased correlation between both CDSs during the sovereign debt crisis, while after this correlation decreased. In the following sections we explain the empirical analyses and the results of each of these two indicators (stock returns and CDS spreads) separately.

[Insert Figures 1, 2, $3 \& 4$ ]

\subsection{Stock returns analysis}

\subsubsection{Selection of the sample}

The purpose of this first analysis is to analyse how the SSM affects banks' stock returns and to test whether contagion from sovereign risk to banks' stock returns differs before and after the SSM. We used quarterly data of stock returns and some other macroeconomic information for an unbalanced panel of 80 banks from 13 eurozone countries ${ }^{7}$ between 2009 and 2016 (2,441 observations). We selected all the eurozone banks with available data in Datastream about stock prices during our sample period. Table 1 shows an overview of the banks and countries that are included in this analysis. All the necessary data come from the Datastream database and the Fama/French - Data Library.

\section{[Insert Table 1]}

\subsubsection{Econometric model and data}

To analyse the effects of the SSM on contagion from sovereign risk to banks' stock returns we used the following model based on the study of Allegret et al. (2016). However, our model introduces the SSM and its interactions with sovereign risk:

$R_{i, t}=\beta_{0}+\beta_{1} S S M_{t}+\beta_{2} S R_{j, t}+\beta_{3} S S M_{t} * S R_{j, t}+\beta_{4} R_{M, t}+\beta_{5} R_{S M B, t}+\beta_{6} R_{H M L, t}+\beta_{7} R_{M O M, t}+\varepsilon_{i, t}$

The dependent variable, $R_{i, t}$, represents the excess return of bank stocks over the risk-free rate (Fama and French 1993; Allegret et al. 2016). It is calculated as the average of the total daily stock returns of bank $i$ in quarter $t$ minus the 10 -year government interest rate.

SSM is a dummy variable that represents the Single Supervision Mechanism and allows us to examine whether the SSM affects banks' stock returns. As we mentioned previously, the SSM entered into force on 4 November 2014, so this variable takes the value of 1 from Q4-2014 to Q4-2016, and 0 otherwise. The effect that the SSM has on banks' stock returns is measured by the coefficient $\beta_{1}$, which is expected to be negative and significant. As Carboni et al. (2017) suggest, the introduction of the SSM penalized banks in the short run because investors expect different supervision of banks under the ECB's direct control with respect to banks remaining with their NSA. This would suggest that investors expect a more intrusive approach by the ECB, or at least are worried about a possibly heterogeneous application of supervision rules for treated and control banks. These facts would worsen banks' performance in the stock market.

$S R$ is the sovereign risk variable and is calculated as the variation in the five-year sovereign CDS spreads in quarter $t$ in relation to quarter $t-1$ (De Bruyckere et al. 2013; Allegret et al. 2016; Yu 2017). The use of this variable allows us to analyse contagion effects from sovereign risk to banks' stock returns. Since we are also interested in analysing how these contagion effects differ before and after the adoption of the SSM, we also included in Equation (1) the interaction term between the SSM dummy and the sovereign risk variable $\left(S S M^{*} S R\right)$. This interaction term follows the base approach, which is the most common way of introducing interaction terms between a dummy variable and another independent variable into a regression (Yip and Tsang, 2007).

\footnotetext{
${ }^{6}$ CDS contracts are bilateral swap agreements mainly transacted in over-the-counter (OTC) derivative markets and allow the CDS seller to provide protection for the buyer. The spreads represent the regular payments that must be paid by the buyer to the seller for the contingent claim in the case of a credit event.

${ }^{7}$ Austria, Belgium, Finland, France, Germany, Greece, Ireland, Italy, Lithuania, the Netherlands, Portugal, Slovakia and Spain.
} 
On the one hand, the coefficient $\beta_{2}$ measures the effects of sovereign risk $(S R)$ on stock returns before the SSM. We expect this coefficient to have a negative and significant sign, since before the SSM an increase in sovereign risk would rapidly reduce the stock returns of the domestic banks (Caselli et al. 2014). On the other hand, the coefficient $\beta_{3}$ captures the differential effects of sovereign risk on stock returns after the SSM in relation to the period before it. The SSM is supposed to reduce interdependencies between sovereigns and banks, so we expect the relationship between sovereign risk and stock returns to be significantly more positive after the SSM than before, which implies that the coefficient $\beta_{3}$ is significant with a positive sign. If this was the case, to test the final effects of sovereign risk on stock returns after the SSM we should conduct a linear restriction test of the sum of the coefficients of $\operatorname{SR}$ and $\operatorname{SR} * S S M\left(\beta_{2}+\beta_{3}\right)$.

$R_{M, t}, R_{S M B, t}, R_{H M L, t}$ and $R_{M O M, t}$ are control variables, based on the four-factor model of Carhart (1997), that capture four common sources of risk across stocks. This is the general framework to control for these common risks because it considers the three-factor model of Fama and French (1993), which accounts for most of the market anomalies left unexplained by the one-factor Sharpe (1964) - Lintner (1965) Capital Asset Pricing Model (CAPM), plus the short-run persistence of returns or momentum effect evidenced by Jegadeesh and Titman (1993). These common risks are the market risk of the CAPM $\left(R_{M, t}\right)$, two nondiversifiable risks (a small size risk $\left(R_{S M B, t}\right)$ and a distress risk $\left.\left(R_{H M L, t}\right)\right)$ and a momentum effect $\left(R_{M O M, t}\right)$.

$R_{M, t}$ is calculated as the difference between the average of the total daily European returns and the 10 -year German government interest rate in quarter $t$.

$R_{S M B, t}$ is the spread between the returns on small and big European stocks.

$R_{H M L, t}$ is the spread between the returns of high book-to-market European stocks (value stocks) and low ones (growth stocks).

$R_{M O M, t}$ is the spread between the returns of past winners (European stocks with the highest prior returns) and past losers (European stocks with the lowest prior returns).

The error term is $\varepsilon_{i, t} ; i=1,2, \ldots ; N$ indicates a specific bank $i ; j=1,2, \ldots ; J$ indicates a particular country $j$; and $t=1,2, \ldots ; T$ indicates a particular quarter $t$.

Table 2 provides a summary of the independent variables and their expected relationship with the dependent variable. Table 3 presents the descriptive statistics of the variables used in the analysis. Table 4 presents the correlations between variables to identify potential collinearity problems.

[Insert Tables 2, 3 \& 4]

We analysed the effects of the SSM on contagion from sovereign risk to stock returns with the panel data methodology because it allows us to account for individual heterogeneity so that it controls for the unobserved differences among banks or changes over time. In addition, panel data also allow us to avoid the problem of possible endogeneity (Hsiao 1985). We estimated Equation (1) with panel regression methods. ${ }^{8}$ The use of this estimation method requires testing whether a fixed- or random-effects model is more suitable. To check whether the fixed-effects or the random-effects model is statistically more efficient, we applied the Hausman test, which tests whether the unique errors $\left(u_{i}\right)$ between banks are correlated with the explanatory variables $\left(\mathrm{X}_{\mathrm{i}, \mathrm{t}}\right)$ (Hausman 1978).

\subsubsection{Empirical results}

Table 5, model (a), presents the results, which show that the p-value of the Hausman test is lower than 0.05 , so we reject the null hypothesis that the unique errors $\left(u_{i}\right)$ are not correlated with the explanatory variables $\left(\mathrm{X}_{\mathrm{i}, \mathrm{t}}\right)$, and therefore the fixed-effects estimator is more consistent.

\section{[Insert Table 5]}

In Table 5, model (a), the variable SSM has a negative and significant coefficient, which implies that the entry into force of the SSM reduces banks' stock returns. As we previously proposed, the adoption of the SSM penalized banks' performance in the stock market, probably because of investors' fear of regulatory inconsistencies and a potential intrusive approach by the ECB (Carboni et al. 2017).

The variable $S R$, which captures the influence of sovereign risk on stock returns before the SSM, is negative and significant. Therefore, before the SSM an increase in sovereign risk leads to a reduction in stock returns. The variable $S S M * S R$, which measures the differential effects of sovereign risk after the SSM with respect to the period before it, is positive and significant. Since $S S M * S R$ is significant, to measure the final effects of sovereign risk on stock returns after the SSM we must carry out a linear restriction test of

\footnotetext{
${ }^{8}$ We thank an anonymous referee for suggesting this methodology to us.
} 
the sum of the coefficients associated with $S R$ and $S S M * S R$ (represented in Table 5, model (a), by LR. Test. $S S M * S R$ ). This linear restriction test is not significant, so we have no evidence that sovereign risk affects stock returns after the SSM.

In order to avoid the SSM dummy variable being confounded with other regulatory changes that came into play during our sample period, we performed additional analyses and replaced the SSM dummy in Equation (1) with other regulatory dummies to check whether other events also affect our results:

-SSMANN: this considers the date when the SSM was officially announced on 19 March 2013. Thus, it takes the value of 1 from Q2-2013 to Q4-2016, and 0 otherwise.

-DRAGHI: this accounts for the famous Mario Draghi's speech on 26 July 2012 to authorize Outright Monetary Transactions (OMTs). So, it takes the value of 1 from Q3-2012 to Q4-2016, and 0 otherwise.

-SRM: this considers the Single Resolution Mechanism, which was the second pillar of the European Banking Union that entered into force on 1 January 2016. Therefore, this dummy takes the value of 1 from Q1-2016 to Q4-2016, and 0 otherwise.

In Table 5, model (b), we analysed the influence of the dummy SSMANN. In this regard, the variable SSMANN is not significant, so the announcement of the SSM does not affect banks' stock returns.

The variable $S R$, which measures the effects of sovereign risk on stock returns before the announcement of the SSM, is negative and significant. On the other hand, the variable $S S M A N N^{*} S R$, which represents the differential effects of sovereign risk after the announcement of the SSM with respect to the period before it, is not significant. So, the effects of sovereign risk on stock returns before the announcement of the SSM are not significantly different from those after this announcement.

In Table 5, model (c), we replaced the SSM dummy with the DRAGHI dummy, which captures the Mario Draghi's famous speech in July 2012 authorizing OMT transactions. The variable DRAGHI shows a positive and significant coefficient, so Draghi's speech has a positive impact on stock returns.

The variable $S R$, which captures the effects of sovereign risk on stock returns before the speech, is negative and significant. However, the interacted variable $D R A G H I * S R$ is not significant, so the negative relationship between sovereign risk and stock returns does not significantly differ before and after Draghi's speech.

In Table 5, model (d), we replaced the SSM dummy with the SRM dummy, which measures the implementation of the second pillar of the European Banking Union, the Single Resolution Mechanism, in January 2016. The variable SRM is negative and significant, thus the entry into force of the SRM reduces banks' stock returns. This result is similar to the one obtained in model (a) regarding the adoption of the SSM, so the implementation of the European Banking Union itself impacts negatively on banks' performance in the stock market. As we mentioned previously, probably, the introduction of the Banking Union led to uncertainties among investors about the new regulatory framework, thereby penalizing banks' stock returns in the short run (Carboni et al. 2017).

The variable $S R$, which reflects the effects of sovereign risk on stock returns before the SRM, is negative and significant. The interaction term between SRM and sovereign risk $(S R M * S R)$ has a positive and significant coefficient, so the effects of sovereign risk on stock returns are significantly more positive after the SRM than before. Thus, we must perform a linear restriction test of the sum of the coefficients associated with $S R$ and $S R M * S R$ (represented in Table 5, model (d), by LR. Test. SRM*SR). This linear restriction test is not significant, so we have no evidence that sovereign risk affects stock returns after the SRM.

With regard to the control variables, the variables $R_{M, t}, R_{S M B, t}$ and $R_{H M L, t}$ are significant with a positive sign in all the models, so the market, small size and distress risk, respectively, positively affect banks' stock returns. ${ }^{9}$

In summary, these results show that the adoption of both the SSM and the SRM negatively affects banks' stock returns. However, despite their negative influence on stock performance, the SSM and the SRM would contribute to reducing contagion from sovereign risk to banks' stock returns. On the one hand,

\footnotetext{
${ }^{9}$ Following the suggestion of an anonymous referee, we have repeated all the analyses by excluding all insignificant explanatory variables and the results are similar to those reported in this article. These results are not shown, but are available on request.
} 
before the SSM and the SRM, respectively, there is a significant negative relationship between sovereign risk and stock returns. However, after the SSM and the SRM, respectively, there is no evidence of this negative relationship. On the other hand, we have no evidence that other previous regulatory measures reduce contagion between sovereigns and banks. In this regard, both before and after the announcement of the SSM and Draghi's speech, respectively, an increase in sovereign risk leads to a decline in banks' stock returns.

\subsubsection{Robustness checks}

To check the robustness of our results, we have repeated all the previous analyses by replacing each individual regulatory dummy ( $S S M$, SSMANN, DRAGHI and SRM) with year dummies to control for year fixed effects. ${ }^{10}$ These results are shown in Table 6.

\section{[Insert Table 6]}

In Table 6, model (a), the variable $S R$ is negative and significant, so before the SSM an increase in sovereign risk leads to a reduction in stock returns. The variable $S S M * S R$ is not significant, so the effects of sovereign risk on stock returns after the SSM are not significantly different from those before the SSM.

In Table 6, model (b), the variable $S R$ has a significant and negative coefficient, which implies that before the announcement of the SSM there is a negative relationship between sovereign risk and stock returns. The variable $S S M A N N^{*} S R$ is also negative and significant, so we must perform a linear restriction test of the sum of the coefficients associated with $S R$ and $S S M A N N^{*} S R$. This linear restriction test has also a negative and significant coefficient and, hence, after the announcement of the SSM, stock returns decrease as sovereign risk rises.

In Table 6, model (c), $S R$ is negative and significant, which is why sovereign risk has a negative impact on stock returns before Draghi's speech. However, this impact is not significantly different after the speech because the variable $D R A G H I^{*} S R$ is not significant.

Finally, we obtain similar results as for the variable $S R M$ in Table 6, model (d), so the negative influence of $S R$ on stock returns is not significantly different after the SRM than before the SRM.

Looking at the results of Tables 5 and 6, we can only conclude that the SSM and the SRM themselves negatively affect stock returns whereas Draghi's speech affects them positively. However, despite its positive influence on stock returns, Draghi's speech does not reduce contagion effects from sovereign risk to banks' stock returns. On the other hand, the announcement of the SSM does not significantly affect stock returns. Moreover, the relationship between sovereign risk and stock returns is negative both before and after the announcement of the SSM, so similar to Draghi's speech, the announcement of the SSM does not reduce contagion. This would suggest that the regulatory measures adopted before the adoption of the SSM in November 2014 do not contribute to mitigating contagion. Probably, as the results of Table 5 suggest, the adoption of the SSM and the SRM would mitigate the negative relationship between sovereign risk and stock returns, however, this evidence is not confirmed by controlling for time dummies. Therefore, we do not have enough evidence that the SSM and the SRM reduce contagion ${ }^{11}$.

\subsection{CDS spreads analysis}

\subsubsection{Selection of the sample}

The purpose of this second analysis is to examine how the adoption of the SSM affects contagion between bank and sovereign risk through CDS spreads. In addition, we test whether this contagion is transmitted from banks to sovereigns or vice versa, and how this transmission differs before and after the SSM. We selected all the eurozone banks with available data regarding CDS in Datastream. Datastream contains data about sovereign CDS for all the eurozone countries except for Luxembourg, but only shows data about bank CDS for 56 banks operating in 10 eurozone countries. Furthermore, since we use quarterly CDS and we need to control for several financial characteristics of banks, we can only include in the sample those banks that also have balance sheets available with quarterly frequency in Datastream. In this regard, 25 out of the 56 banks mentioned previously fulfil this criterion. ${ }^{12}$ Therefore, we obtained CDS spread series and some other financial and macroeconomic information for an unbalanced selection of 25 banks

\footnotetext{
${ }^{10}$ We thank an anonymous referee for this suggestion.

${ }^{11}$ As regards the control variables in Table 6, only $R_{H M L, t}$ (distress risk) is significant with a positive sign in all the models.

${ }^{12}$ De Bruyckere et al. (2013) also had a similar sample size for Eurozone banks in an analysis of contagion between bank and sovereign CDS spreads.
} 
from 10 eurozone countries ${ }^{13}$ between 2009 and 2016 (771 observations). Table 7 shows an overview of the banks and countries that are included in this analysis. CDS spreads data and each bank's financial information come from the Datastream database, while the home country macroeconomic data of each bank come from the OECD statistics, the ECB and the Bruegel database.

\section{[Insert Table 7]}

\subsubsection{Methodology and econometric model}

To measure bank and sovereign credit risk, we used the spreads on credit default swaps (CDSs). In line with other studies, we use CDS spreads on five-year senior debt contracts, since these are considered to be the most actively traded and the most liquid ones (Anderson 2011; Alter and Schüler 2012; Aizenman et al. 2013; De Bruyckere et al. 2013; Yu 2017).

Using CDS spreads as credit risk proxies provides several advantages (Aizenman et al. 2013). First, they reflect timelier market perceptions of risk, while other risk measures, such as rating agencies, take more time before changing the rating of entities. Second, government and bond yields, which can also be used as credit risk variables, have the difficulty of dealing with time to maturity and include, apart from default risk, inflation expectations and demand/supply for credit conditions. However, CDS spreads capture explicitly default risk, which is the only variable in which we are interested.

One starting point to measure contagion could be looking at simple (raw) correlations between bank and sovereign credit risk indicators. However, focusing on raw correlations to capture contagion can be biased, especially in times of crisis, since higher correlations would be expected in periods of higher volatility (Forbes and Rigobon 2002). To avoid this bias, contagion is defined as excess correlation, which is correlation over and above what one would expect from economic fundamentals or common factors (Bekaert et al. 2005; Pasquariello 2007).

Following the approach of Anderson (2011) and De Bruyckere et al. (2013), to measure this excess correlation we first define a factor model where we decompose raw correlations into fundamental and excess correlations by assuming that CDS spread changes follow a linear factor structure. According to this assumption, the raw correlation between CDS spread changes of bank $i$ and its home country $j$ in period $t$ can be decomposed as follows:

$$
E\left[\Delta C D S_{i, t} \Delta C D S_{j, t}^{\prime}\right]=E\left[\left(\beta_{i} F^{\prime}+\varepsilon_{i, t}\right)\left(\beta_{j} F^{\prime}+\varepsilon_{j, t}\right)^{\prime}\right]=\beta_{i} E\left[F^{\prime} F\right] \beta_{j}^{\prime}+E\left[\varepsilon_{i, t} \varepsilon_{j, t}^{\prime}\right]
$$

where $\triangle C D S$ is an Nx1 vector of CDS spread changes, $\beta$ is an NxK matrix of factor exposures, $F$ is a $1 \times$ K vector of common factors that affect bank and sovereign CDS spreads simultaneously, and $\varepsilon$ is an $\mathrm{Nx} 1$ vector of model errors (estimated residuals). This decomposition provides two covariance matrices: $\beta_{i} E\left[F^{\prime} F\right] \beta^{\prime}{ }_{j}$ and $E\left[\varepsilon_{i, t} \varepsilon^{\prime}{ }_{j, t}\right]$. The excess correlation is computed by extracting from the correlation matrix the estimated residuals: $E\left[\varepsilon_{i, t} \varepsilon^{\prime}{ }_{j, t}\right]$.

Equation (2) suggests that greater correlation between bank and sovereign credit risk may be for three reasons (Anderson 2011): (i) an increase in exposure of CDS spread changes to common factors; (ii) increased correlation between the common factors; and (iii) an increase in the correlation between unexplained CDS spread changes, which is considered contagion.

Consequently, when the increase in raw correlation is completely due to common factors, the excess correlation will be zero. However, when bank and sovereign CDS spread changes are still correlated after controlling for common factors, this will be an evidence of contagion between the bank and the country level. In order to measure this contagion and how the SSM affects it, we follow a three-step procedure (De Bruyckere et al. 2013): first, we estimate the residuals of a regression on some common determinants of bank and sovereign CDS spreads, using daily data; next, we estimate the quarterly correlation between the bank and sovereign CDS residuals; finally, we regress these quarterly correlations on SSM and other explanatory variables. Each of these three steps is explained below.

With regard to the first step, we control for the common factors that affect bank and sovereign CDS, by regressing CDS spread changes on four state variables (De Bruyckere et al. 2013):

$$
\Delta C D S_{i, t}=c+\beta_{1} \text { Market }_{t}+\beta_{2} \text { iTraxx }_{t}+\beta_{3} \text { Vstoxx }_{t}+\beta_{4} \text { Term }_{t}+\varepsilon_{i, t}
$$

$\triangle C D S$ is the change in CDS spread for bank or country $i$. Market is the total stock market index for the European Union and is an indicator of business climate. A better business climate reduces the probability of default, and thus we would expect a negative sign for the Market variable in the factor model

\footnotetext{
${ }^{13}$ Austria, Belgium, France, Germany, Greece, Ireland, Italy, the Netherlands, Portugal and Spain.
} 
(Alter and Beyer 2014; Yu 2017). iTraxx is an index of the equally weighted average of the 125 most liquid CDS series in Europe. A higher iTraxx represents a higher overall default risk in the economy; therefore, we expect a positive sign for this variable (Berndt and Obreja 2010; Ejsing and Lemke 2011). Vstoxx is a volatility index and captures market expectations. A higher volatility causes greater uncertainty, so this variable should have a positive sign (Fontana and Scheicher 2010; Drago and Gallo 2016). Term is the difference between the 10-year government bond yield for each country and the one-year Euribor rate. It is a proxy for market expectations about future conditions in the financial market. We expect a negative relationship between the variable Term and CDS spreads (De Bruyckere et al. 2013). ${ }^{14}$ We regress these factor models for each bank and country using daily data.

For the second step of our procedure, from each regression of CDS spread variation, we compute excess correlation as the correlation between the residuals $\left(\varepsilon_{i, t}\right)$ of a bank and those of its respective home country in a specific quarter. ${ }^{15}$ This excess correlation is the one that still exists after controlling for common factors and hence constitutes evidence of contagion between bank and sovereign risk (De Bruyckere et al. 2013; Alter and Beyer 2014). Figures 5 and 6 show the time evolution of the quarterly averages of these residuals and of the correlations respectively between 2009 and 2016. Figure 5 reveals that both bank and sovereign residuals follow a similar trend. In general, both average residuals experience greater variations before the adoption of the SSM, mainly between 2009 and 2011, while after the SSM, the values of both residuals are closer to zero. Figure 6 shows that correlations between bank and sovereign residuals change constantly throughout the period, especially before the SSM. On average, these correlations range from 0.102 to 0.367 before the SSM, whereas after the SSM they range from 0.073 to 0.233 .

\section{[Insert Figures 5 \& 6]}

Finally, in the third step of our procedure we regress the quarterly correlations between bank and sovereign CDS spread residuals on SSM and other explanatory variables. This step allows us to analyse the effects of the SSM and CDS spread variations on contagion between bank and sovereign risk. We propose the following model based on the approach of De Bruyckere et al. (2013). However, our article includes the SSM and its interactions with sovereign and bank CDS spread variations:

$$
\begin{gathered}
\operatorname{EXCCORR}_{i, j, t}=\beta_{0}+\beta_{1} \operatorname{SSM}_{t}+\beta_{2} \Delta \operatorname{CDS}_{\text {Bank }_{i, j, t}}+\beta_{3} \operatorname{SSM}_{t} * \Delta \operatorname{CDS}_{\text {Bank }_{i, j, t}}+\beta_{4} \Delta \operatorname{CDS}_{\text {Sov }_{i, j, t}}+ \\
\beta_{5} \operatorname{SSM}_{t} * \Delta C D S_{\text {Sov }_{i, j, t}}+\beta_{6} \operatorname{SIZE}_{i, t}+\beta_{7} \operatorname{CAP}_{i, t}+\beta_{8} \text { RETAIL }_{i, t}+\beta_{9} \text { FUNDSTRUC }_{i, t}+\beta_{10} \operatorname{MES}_{i, t}+ \\
\beta_{11} \Delta G D P_{j, t}+\beta_{12} \operatorname{PUBDEBT}_{j, t}+\beta_{13} \text { FISCBAL }_{j, t}+\varepsilon_{i, t}
\end{gathered}
$$

The dependent variable, EXCCORR $R_{i, j, t}$, represents the excess correlation between the CDS spreads of bank $i$ and its home country $j$ in quarter $t$ (De Bruyckere et al. 2013; Alter and Beyer 2014). ${ }^{16}$ It is a proxy for contagion between bank and sovereign credit risk and, as we mentioned previously, it is calculated as the correlation between the estimated residuals in the factor model regressions of Equation (3).

SSM is a dummy variable that represents the Single Supervision Mechanism and allows us to analyse whether the SSM affects excess correlations between bank and sovereign risk. This variable takes the value of 1 from Q4-2014 to Q4-2016, and 0 otherwise. The effect that the SSM has on excess correlations is measured by the coefficient $\beta_{l}$, which is expected to be negative and significant. As we mentioned previously, one of the main purposes of the SSM is to introduce more homogeneous financial conditions for all banks, to improve the health of the banking system and make banks less likely to fail, thereby reducing the interdependency between sovereign and bank risk.

$\triangle C D S_{\text {Bank }}$ represents bank CDS spread variations in quarter $t$ in relation to quarter $t-1$. The use of this variable allows us to analyse how an increase in bank risk affects contagion between bank and sovereign risk. Since we are also interested in analysing how these effects differ before and after the adoption of the SSM, we also include in Equation (4) the interaction term between the SSM dummy and the bank risk variable $\left(S S M^{*} \triangle C D S_{\text {Bank }}\right)$. The coefficient $\beta_{2}$ measures the effects of bank risk $\left(\triangle C D S_{\text {Bank }}\right)$ on contagion before the SSM. We expect this coefficient to have a positive and significant sign because before the SSM, an increase in bank risk would lead to greater contagion (Gray et al. 2008; Ejsing and Lemke 2011; Alter and Schüler 2012). On the other hand, the coefficient $\beta_{3}$ captures the differential effects of bank risk on

\footnotetext{
${ }^{14}$ All state variables come from Datastream and are transformed into arithmetic returns, except for the variable Term, which is included in first differences (De Bruyckere et al. 2013).

${ }^{15}$ Following the suggestion of an anonymous referee, we clustered the standard errors of the regressions by year and country.

${ }^{16}$ We calculate excess correlations on a quarterly basis using daily CDS data, because quarterly frequency is the highest frequency for which there is bank balance sheet data available in Datastream (De Bruyckere et al. 2013).
} 
contagion after the SSM in relation to the period before it. The effects that bank risk has on contagion should have been reduced after the SSM (Leblond 2014; Nowotny 2014), so we expect the coefficient $\beta_{3}$ to be significant with a negative sign. If this was the case, to test the final effects of bank risk on contagion after the SSM, we should conduct a linear restriction test of the sum of the coefficients of $\triangle C D S_{\text {Bank }}$ and $S S M^{*} \Delta C D S_{\text {Bank }}\left(\beta_{2}+\beta_{3}\right)$.

Apart from bank risk, we also included in Equation (4) a sovereign risk variable, denoted by $\triangle C D S_{\text {Sov }}$, and its interaction with the $\operatorname{SSM}\left(S S M^{*} \Delta C D S_{\text {Sov }}\right) .{ }^{17}$ On the one hand, the coefficient $\beta_{4}$ captures the effects of sovereign risk on contagion before the SSM. We expect this coefficient to be positive and significant because before the SSM an increase in sovereign risk will produce greater contagion (Arezki et al. 2011; Correa et al. 2012; Gennaioli et al. 2014). On the other hand, the coefficient $\beta_{5}$ represents the differential effects of sovereign risk on contagion after the SSM in relation to the period before it. Similarly to bank risk, we expect the relationship between sovereign risk and contagion to be significantly more negative after the SSM than before, so we expect the coefficient $\beta_{5}$ to be negative and significant. To test the final effects of sovereign risk on contagion after the SSM, we perform a linear restriction test of the sum of the coefficients of $\triangle C D S_{\text {Sov }}$ and $S S M^{*} \triangle C D S_{\text {Sov }}\left(\beta_{4}+\beta_{5}\right)$.

The inclusion of both bank and sovereign risk variables $\left(\triangle C D S_{\text {Bank }}\right.$ and $\left.\triangle C D S_{S o v}\right)$ and their interactions with the $\operatorname{SSM}\left(S S M^{*} \triangle C D S_{\text {Bank }}\right.$ and $\left.S S M^{*} \triangle C D S_{S o v}\right)$ in the same equation ${ }^{18}$ serves to identify more precisely whether contagion between bank and sovereign risk is transmitted from banks to sovereigns or vice versa, and how the direction of this transmission is conditioned by the introduction of the SSM.

SIZE is the ratio of each bank's total assets to its home country gross domestic product (GDP) and serves to control for the size of a bank (De Bruyckere et al. 2013). In periods of financial instability, larger banks are more likely to be a source of financial risk to governments, since these banks will require a bailout in the case of default (Gerlach et al. 2010). This would increase the default risk co-movement with their home country. Therefore, we could expect a significant and positive relationship between the bank size and the excess correlations.

$C A P$ is the risk-weighted Tier 1 capital ratio. Better-capitalized banks are less likely to need government support, since these banks are better able to absorb losses arising from bad assets (Baele et al. 2007; Gerlach et al. 2010; Altunbas et al. 2011). Consequently, higher levels of capital should reduce excess correlation between bank and sovereign risk.

RETAIL denotes the loan-to-assets ratio and is an indicator of banks' retail orientation. Retail banks are perceived as less risky than the non-retail ones, especially during a crisis. Additionally, banks with higher levels of loans have a lower proportion of securities, which reduces their exposure to sovereign bonds (De Bruyckere et al. 2013). Therefore, there should be a negative and significant relationship between the variable RETAIL and excess correlation.

FUNDSTRUC is the level of short-term market debt over total liabilities and equity and represents a proxy for each bank's funding structure. Banks that rely more on wholesale funding instead of deposits are considered more risky, especially during a crisis, when market-based funding is very volatile (Altunbas et al. 2011). This greater bank risk can be transmitted to the sovereign, so we expect a positive relationship between the funding structure of a bank and the excess correlation.

$M E S$ denotes marginal expected shortfall and is a proxy of the exposure of each bank to systemic risk. It is calculated as the average return of each bank during the 5\% worst days for the European market in quarter $t$, so it represents the expected equity loss when the market itself is in its left tail (Idier et al. 2014; Acharya et al. 2017; Jiang et al. 2017). Higher exposure to systemic risk would lead to greater contagion, so we expect this variable to have a positive and significant coefficient.

$\triangle G D P$ is the GDP growth of country $j$ in quarter $t$ in relation to quarter $t-1$ and accounts for both business cycle conditions and bank growth opportunities (De Bruyckere et al. 2013; Demirgüç-Kunt and Huizinga 2013). On the one hand, economic recessions may amplify banking crises and worsen the financial situation of the public sector, which will increase both bank and sovereign CDS spreads. If both banks and sovereigns increase their CDS, their correlations will be greater. Consequently, a negative relationship can be expected between GDP growth and excess correlations. However, higher growth opportunities and better economic conditions are expected to increase bank valuation and to improve the soundness of public finances, which will reduce both bank and sovereign CDS spreads. If both banks and

\footnotetext{
${ }^{17}$ Quarterly bank and sovereign CDS are calculated as the average of the daily CDS of each quarter. Demirgüç-Kunt and Huizinga (2013) followed a similar approach to compute annual CDS from daily data.

${ }^{18}$ We thank an anonymous referee for this suggestion.
} 
sovereigns reduced their CDS, the correlation between them would also be higher. Hence, a positive and significant coefficient for GDP growth is also expected.

PUBDEBT represents the ratio of public debt to GDP for country $j$. Greater levels of this ratio produce an increase in sovereign risk, which can be transmitted to the banking sector (Gerlach et al. 2010; Kallestrup et al. 2016). Thus, we expect a positive and significant relationship between PUBDEBT and excess correlations.

FISCBAL is the fiscal balance and is calculated as government revenues minus expenses divided by GDP (Demirgüç-Kunt and Huizinga 2013). Higher fiscal balances imply stronger public finances, which will reduce the interdependency between banks and sovereigns. Therefore, we expect a negative relationship between FISCBAL and excess correlation.

According to De Bruyckere et al. (2013), all the control variables are standardized, which implies that the coefficients show the impact of a one standard deviation change of these control variables on the excess correlation between bank and sovereign CDS spreads. ${ }^{19}$

The error term is $\varepsilon_{i, t} ; i=1,2, \ldots ; N$ indicates a specific bank $i ; j=1,2, \ldots ; J$ indicates a particular country $j$; and $t=1,2, \ldots ; T$ indicates a particular quarter $t .^{20}$

Table 8 provides a summary of the independent variables and their expected relationship with the dependent variable. Table 9 presents the descriptive statistics of the variables used in the analysis. Table 10 presents the correlations between variables to identify potential collinearity problems.

[Insert Tables 8, $9 \& 10]$

Similarly to the stock return analysis, the empirical estimation of Equation (4) was performed using panel regression models. The Hausman specification test was also conducted to decide between fixedeffects and random-effects estimators in each model (Hausman 1978).

\subsubsection{Empirical results}

Table 11, model (a), shows the results. The results of the Hausman test show that the fixed-effects estimator is more consistent ( $\mathrm{p}$-value $<0.05)$.

\section{[Insert Table 11]}

In Table 11, model (a), the variable SSM is significant with a negative coefficient. Thus, the adoption of the SSM leads to a reduction in contagion between bank and sovereign CDS spreads.

The variable $\triangle C D S_{\text {Bank }}$, which measures the effects of bank CDS growth on contagion before the SSM, is positive with a significant coefficient. This implies that before the SSM, an increase in bank CDS spreads leads to greater contagion between bank and sovereign CDS spreads. However, $S S M^{*} \Delta C D S_{\text {Bank }}$ is not significant, so the differential effects of bank risk on contagion after the adoption of the SSM are not statistically significantly different from those before. Consequently, there is no evidence that the adoption of the SSM reduces contagion from bank to sovereign CDS spreads.

The variable $\triangle C D S_{S o v}$, which measures the effects of sovereign risk on contagion before the SSM, is not significant. In addition, the variable $S S M^{*} \triangle C D S_{S o v}$ is not significant either, so the differential effects of sovereign risk would not vary significantly before or after the adoption of the SSM. This would suggest that an increase in sovereign risk does not affect contagion through CDS spreads, either before or after the implementation of the SSM.

Similarly to the stock returns analysis, we performed additional estimations and replaced the SSM dummy in Equation (4) with other dummies that capture other regulatory changes that came into play during our sample period (SSMANN, DRAGHI and SRM). These additional estimations allow us to ensure that our results are explicitly due to the entry into force of the SSM and not to other events.

\footnotetext{
${ }^{19}$ Control variables are standardized by calculating the deviation from the average and dividing this by the standard deviation of the variable. Bank-specific variables are standardized at the bank level, while macroeconomic variables are standardized at the country level.

${ }^{20}$ We do not include country dummies in our model, since some countries of the sample contain only one bank, and hence the country dummies in this case could be biased by the situation of the specific bank instead of representing the global situation of the country. Instead, we use macroeconomic variables to control for the situation of the country, such as the GDP growth $(\triangle G D P)$, the public debt ratio (PUBDEBT) and the fiscal balance (FISCBAL).
} 
In Table 11, model (b), the variable SSMANN is negative and significant, so the announcement of the SSM also reduces contagion between bank and sovereign CDS spreads, which suggests that the effects of the SSM are already noticeable from the very beginning of its announcement.

The variable $\triangle C D S_{\text {Bank, }}$, which captures the effects of bank risk before the announcement of the SSM, is positive with a significant coefficient. So, before the announcement of the SSM, an increase in bank risk produces greater contagion. However, $S S M A N N^{*} \triangle C D S_{B a n k}$, which controls for the differential effects of bank risk after the announcement of the SSM in relation to before, is not significant. Similarly to model (a), the effects of bank risk on contagion after the announcement of the SSM do not significantly vary with respect to the period before it.

The variable $\triangle C D S_{S o v}$, which measures the effects of sovereign risk on contagion before the announcement of the SSM, is not significant. However, $S S M A N N^{*} \triangle C D S_{S o v}$ is negative and significant, which means that the impact of sovereign risk on contagion is significantly more negative after the announcement of the SSM than before. Therefore, we must perform the linear restriction test of the sum of the coefficients of $\triangle C D S_{S o v}$ and $S S M A N N^{*} \triangle C D S_{\text {Sov }}$ (denoted by LR Test. SSMANN* $\triangle C D S_{\text {Sov }}$ in Table 11, model (b)). LR Test. SSMANN* $\triangle C D S_{\text {Sov }}$, which measures the effect of sovereign risk on contagion after the announcement of the SSM, is negative and significant. Consequently, after the announcement of the SSM, an increase in sovereign risk reduces excess correlations. Probably, after the announcement of the SSM, bank CDS spreads do not react to an increase in sovereign CDS spreads, thereby reducing contagion between both types of CDS.

The results from model (b) would suggest that the announcement of the SSM in March 2013 reduces contagion between bank and sovereign risk, and the direction of this reduction is only explained by the lower impact of sovereign risk on bank risk, and not vice versa.

In Table 11, model (c), we replaced the SSM dummy with the DRAGHI dummy, which captures Draghi's speech in July 2012 authorizing OMT transactions. The variable DRAGHI shows a negative and significant coefficient, so Draghi's speech reduces excess correlations.

The variable $\triangle C D S_{\text {Bank }}$ is positive with a significant coefficient, so before Draghi's speech, an increase in bank risk leads to greater contagion between bank and sovereign risk. However, $D R A G H I^{*} \triangle C D S_{\text {Bank }}$ is not significant, so there are no significant differences in the relationship between bank risk and contagion after or before the speech.

The variable $\triangle C D S_{S o v}$ is not significant, so before the speech, an increase in sovereign risk does not alter the level of contagion between bank and sovereign risk. Moreover, $D R A G H I^{*} \triangle C D S_{S o v}$ is not significant either, and therefore the effects of sovereign risk on contagion do not vary significantly after the speech with respect to the period before. This shows that the observed reduction in contagion from sovereign to bank risk observed in model (b) is explicitly due to the announcement of the SSM and not to the previous speech of Draghi.

In Table 11, model (d), we replaced the SSM dummy with the SRM dummy, which represents the implementation of the second pillar of the European Banking Union, the Single Resolution Mechanism, in January 2016. The variable $S R M$ is not significant, thus the entry into force of the SRM itself does not affect contagion between bank and sovereign risk.

The variable $\triangle C D S_{\text {Bank }}$ is positive with a significant coefficient, whereas $S R M^{*} \triangle C D S_{\text {Bank }}$ is not significant. This implies that before the SRM, there is a positive relationship between bank risk and contagion, and this relationship does not significantly change after the SRM in relation to before. In terms of sovereign risk, the variables $\triangle C D S_{\text {Sov }}$ and $S R M^{*} \triangle C D S_{\text {Sov }}$ are not significant. Thus, an increase in sovereign risk does not affect contagion through CDS spreads, either before or after the $\mathrm{SRM}^{21}$.

\subsubsection{Robustness checks}

Similarly to the stock returns analysis, to check the robustness of our results, we have repeated the previous estimations and replaced each individual regulatory dummy (SSM, SSMANN, DRAGHI and SRM) with year dummies to control for year fixed effects ${ }^{22}$ (see Table 12). The results stated in Table 12 under models (a), (b), (c), and (d) show that the p-value of the Hausman test is greater than 0.05, so the randomeffects estimator is more consistent.

\footnotetext{
${ }^{21}$ Following the suggestion of an anonymous referee, we have repeated the previous analyses by excluding all insignificant explanatory variables and the results are similar. These results are not reported, but are available on request.

${ }^{22}$ We thank an anonymous referee for this suggestion.
} 


\section{[Insert Table 12]}

The results from Table 12 show that only the announcement of the SSM (SSMANN in model (b)) has a significant effect on contagion, since in the rest of the models, (a), (c) and (d), our variables of interest are not significant. In this regards, in model (a), the variables $\triangle C D S_{\text {Bank }}, S S M^{*} \triangle C D S_{\text {Bank }}, \triangle C D S_{\text {Sov }}$ and $S S M^{*} \triangle C D S_{S o v}$ are not significant, so either bank or sovereign risk do not significantly affect contagion either before or after the adoption of the SSM. In model (c), the variables $\triangle C D S_{\text {Bank }}, D R A G H I^{*} \triangle C D S_{\text {Bank }}$, $\triangle C D S_{\text {Sov }}$ and $D R A G H I^{*} \triangle C D S_{\text {Sov }}$ are not significant and, hence, there are no significant interdependencies between bank and sovereign risk either before or after Draghi's speech. Besides, in model (d), the variables $\triangle C D S_{\text {Bank }}, S R M^{*} \triangle C D S_{\text {Bank }}, \triangle C D S_{\text {Sov }}$ and $S R M^{*} \triangle C D S_{\text {Sov }}$ are not significant, which means that there is no significant contagion from bank to sovereign risk, or vice versa, either before or after the SRM.

With regard to model (b), the variable $\triangle C D S_{B a n k}$, which measures the effects of bank risk on contagion before the announcement of the SSM, is not significant. In addition, $S S M A N N^{*} \triangle C D S_{\text {Bank }}$ is not significant either, so the effects of bank risk on contagion after the announcement of the SSM are not significantly different from those before. The results from this model would not show evidence of contagion from bank to sovereign risk either before or after the announcement of the SSM.

The variable $\triangle C D S_{S o v}$, which captures the influence of sovereign risk on contagion before the announcement of the SSM, is not significant. However, $S S M A N N^{*} \triangle C D S_{S o v}$ is significant with a negative sign, so the effects of sovereign risk on contagion are significantly more negative after the announcement of the SSM than before. If we consider the linear restriction test LR Test., SSMANN* $\triangle C D S_{S o v}$, which measures the impact of an increase in sovereign risk after the announcement of the SSM, is significant with a negative sign. So, as indicated previously, the announcement of the SSM has significantly reduced contagion from sovereign to bank risk.

Looking jointly at the results of Tables 11 and 12, they would support the idea that only the announcement of the SSM in March 2013 has reduced contagion between bank and sovereign risk through CDS. In addition, this contagion reduction is only explained by the lower impact of sovereign risk on bank risk after this announcement, and not vice versa. Before the announcement of the SSM, an increase in sovereign CDS spreads does not modify the degree of contagion between bank and sovereign risk. However, after the announcement of the SSM, an increase in sovereign CDS spreads leads to lower contagion, probably because bank risk does not react to an increase in sovereign risk, thereby reducing contagion between both types of risk. However, we have no evidence that other regulatory measures reduce contagion through CDS. Moreover, contrary to banks' stock returns where there is not enough evidence, CDS spreads' response occurs immediately after the announcement of the SSM.

As additional robustness checks, we have repeated the analyses by controlling for bank holdings of sovereign debt. ${ }^{23}$ Therefore, we included in Equation (4) the variable SOVHOLD, which represents resident banks' exposure to sovereign bond holdings in a specific country in quarter $t$. These data come from the Bruegel database of sovereign bond holdings developed in Merler and Pisani-Ferri (2012). ${ }^{24}$ The results of the robustness checks are similar to those reported previously. ${ }^{25}$

\subsection{Discussion}

This article analyses how the adoption of the SSM affects contagion between bank and sovereign risk. On the one hand, using stock price data, we show that the implementation of the European Banking Union negatively affects banks' stock returns, since the adoption of both the SSM and the SRM, the first two pillars, impacts negatively on banks' performance in the stock market. However, we do not find solid evidence that the SSM and the SRM reduce contagion from sovereign risk to stock returns. On the other hand, using CDS spreads, we find that only the announcement of the SSM in March 2013 reduces contagion between bank and sovereign risk. Moreover, the reduction in this contagion is determined by the lower influence of sovereign risk on bank risk after the announcement, and not vice versa. Before the announcement of the SSM, an increase in sovereign risk does not alter contagion, but after, an increase in sovereign risk produces lower contagion, probably because bank risk does not react, which reduces interdependencies between the two types of risk.

\footnotetext{
${ }^{23}$ We thank an anonymous referee for this suggestion.

${ }^{24}$ This database does not contain quarterly information about resident banks' sovereign debt holdings either for Austria and Belgium throughout the whole sample period or for Germany from Q3-2015. So, the robustness checks comprise 22 banks and eight countries (671 observations).

${ }^{25}$ These results are not shown in the article but are available on request.
} 
These results reveal a different reaction between CDS spreads and stock prices, since the former reacts immediately to the announcement of the SSM, whereas there is not consistent evidence for stock prices. These results are in line with other studies that show that stock prices underreact to positive news, especially in bad times because investors tend to bear more uncertainties during recessions (McQueen et al. 1996; Veronesi 1999). Moreover, our results are consistent with the evidence obtained by Giannikos et al. (2013), who find that during the recent financial crisis the financial sector's CDS market is more responsive to new information. These authors support this more dominant role in price discovery of the CDS market with behavioral finance models, which suggest that, before the crisis, a more stable equity market led investors to feel overconfident, which increased speculative noise trading (Odean 1998; Gervais and Odean 2001; Statman et al. 2006). Informed traders would prefer to speculate on the CDS market because the derivative markets provide more leverage and make it easier for traders to hide informed trades (Black 1975; Easley et al. 1998). However, during the crisis, the market is very volatile and hence much less conducive to noise trading. The reduction of noise trading in the CDS market improves the quality of the CDS prices, and strengthens the role of the CDS market in price discovery.

\section{Conclusions}

The financial crisis that started in 2008 raised investor concerns about sovereign risk in several European countries, which negatively affected the financial situation of the domestic banking sector and increased bank risk. Additionally, weak capital positions and liquidity problems in the banking system during the crisis were transmitted to the soundness of public finances, thereby increasing sovereign risk. These facts generated a vicious circle between bank and sovereign risk, which seriously damaged the stability of the global financial system.

To break this contagion between bank and sovereign risk, the European Banking Union was proposed in 2012, consisting of three pillars: the Single Supervision Mechanism (SSM), the Single Resolution Mechanism (SRM) and the common Deposit Guarantee Scheme (DGS). The SSM was the first pillar to enter into force on 4 November 2014, when the ECB became the major supervisor of European banks in collaboration with the NSA of each country.

This article analyses how the adoption of the SSM affects contagion between bank and sovereign risk. Additionally, we test whether the effects of a variation in bank and sovereign risk on this contagion differ before and after the SSM. The SSM is supposed to reduce contagion between banks and sovereigns, since it implies applying common rules to all banks, which will lead to more homogeneous funding conditions and will make banks less dependent on their home country's sovereign risk. This will reduce the uncertainty premiums that some banks pay. Moreover, the SSM will improve the health of the banking system and will enable the direct intervention of the ESM to provide temporary financial assistance to troubled banks, so governments do not need to rescue systemic banks and the risk of spillovers from banks to sovereigns will be reduced.

We perform an empirical analysis based on two indicators: banks' stock returns and CDS spreads. The analysis of stock returns comprises quarterly data from 80 banks and 13 eurozone countries between 2009 and 2016 (2,441 observations). We do not have solid evidence that the SSM reduces contagion from sovereign risk to banks' stock returns. The analysis of CDS spreads is based on quarterly data from 25 banks and 10 eurozone countries over the period 2009-2016 (771 observations). We find that only the announcement of the SSM in March 2013 reduces contagion between bank and sovereign risk. In addition, before the announcement of the SSM, an increase in sovereign risk does not alter the degree of contagion, while after this announcement, an increase in sovereign risk leads to lower contagion. Consequently, CDS spreads react immediately to the announcement of the SSM, but there is not consistent evidence for banks' stock returns, probably because during the recent crisis, the financial sector's CDS market played a more dominant role in price discovery, whereas stock prices normally underreact to good news in recession periods.

This article has tried to shed light on the effects of the SSM on contagion between banks and sovereigns during its first quarters of operation. However, the SSM also poses several issues, especially in the long run. For instance, there can be potential conflicting objectives between the ECB and the NSA of each country, difficulties dealing with European countries that do not participate in the SSM, or possible conflicting relationships between micro- and macro-prudential supervision. In addition, there are still uncertainties about the ECB's ability to stabilize the banking system, since its main role is to ensure price stability. Thus, further research is needed to fully understand the effectiveness of the SSM in the long run. 


\section{References}

Acharya, V. V., Drechsler, I., \& Schnabl, P. (2014). A pyrrhic victory? Bank bailouts and sovereign credit risk. The Journal of Finance, 69 (6), 2689-2739.

Acharya, V. V., Pedersen, H. L., Philippon, T., \& Richardson, M. (2017). Measuring systemic risk. The Review of Financial Studies, 30 (1), 2-47.

Adelino, M., \& Ferreira, M.A. (2016). Bank ratings and lending supply: Evidence from sovereign downgrades. The Review of Financial Studies, 29 (7), 1709-1746.

Aizenman, J., Hutchison, M., \& Jinjarak, Y. (2013). What is the risk of European sovereign debt defaults? Fiscal space, CDS spreads and market pricing of risk. Journal of International Money and Finance, 34 (1), 37-59.

Allegret, J. P., Raymond, H., \& Rharrabti, H. (2016). The impact of the eurozone crisis on European banks stocks contagion or interdependence? European Research Studies, 19 (1), 129-148.

Alsakka, R., ap Gwilym, O., \& Vu, T. N. (2014). The sovereign-rating channel and rating agencies' downgrades during the European debt crisis. Journal of International Money and Finance, 49, 235257.

Altavilla, C., Pagano, M., \& Simonelli, S. (2016). Bank exposures and sovereign stress transmission. European Systemic Risk Board. Working Paper Series No. 11/ May 2016.

Alter, A., \& Beyer, A. (2014). The dynamics of spillover effects during the European sovereign debt turmoil. Journal of Banking and Finance, 42, 134-153.

Alter, A., \& Schüler, Y.S. (2012). Credit spread interdependencies of European states and banks during the financial crisis. Journal of Banking and Finance, 36, 3444-3468.

Altunbas, Y., Manganelli, S., \& Marques-Ibanez, D. (2011). Bank risk during the financial crisis: Do business models matter? ECB Working Paper, 1394.

Anderson, M. (2011). Contagion and excess correlation in credit default swaps. Working Paper, George Mason University.

Angeloni, C., \& Wolff, G.B. (2012). Are banks affected by their holdings of government debt? Bruegel Working Paper, (2012/07).

Angeloni, I. (2015). The Single Supervisory Mechanism. European Economy. Banks, Regulation and the Real Sector, 1(3), 43-55.

Arezki, R., Candelon, B., \& Sy, A. (2011). Sovereign rating news and financial markets spillovers: Evidence from the European debt crisis. IMF Working Paper, 68.

Baele, L., De Jonghe, O., \& Vander Vennet, R. (2007). Does the stock market value bank diversification? Journal of Banking and Finance, 31 (7), 1999-2023.

Barba-Navaretti, G., Calzolari, G., \& Franco-Pozzolo, A. (2015). Sand in the wheels: Implementing the Single Supervision Mechanism and multinational banking in Europe. European Economy. Banks, Regulation and the Real Sector, 1(3), 9-23.

Barth, J. R., Prabha, A., \& Yun, G. (2012). The eurozone financial crisis: Role of interdependencies between bank and sovereign risk. Journal of Financial Economic Policy, 4(1), 76-97.

Bekaert, G., Harvey, C., \& Ng, A. (2005). Market integration and contagion. Journal of Business, 78(1), 39-69.

Berndt, A., \& Obreja, I. (2010). Decomposing European CDS returns. Review of Finance, 14,189-233.

Black, F. (1975). Fact and fantasy in use of Options. Financial Analysts Journal, 31, 61-72.

Bocola, L. (2016). The pass-through of sovereign risk. Journal of Political Economy, 124(4), 879-926.

Bolton, P., \& Jeanne, O. (2011). Sovereign default risk and bank fragility in financially integrated economies. IMF Economic Review, 59 (2), 162-194.

Borenzstein, E., Cowan, K., \& Valenzuela, P. (2013). The sovereign ceiling lite and bank credit ratings in emerging market economies. Journal of Banking and Finance, 37 (11), 4014-4024.

Breton, R., Pinto, C., \& Weber, P.F. (2012). Banks, moral hazard and public debts. Financial Stability Review, 16, 57-70.

Brown, C., \& Dinc, I. (2011). Too many to fail? Evidence of regulatory forbearance when the banking sector is weak. Review of Financial Studies, 24 (4), 1378-1405.

Buch, C. M., Koetter, M., \& Ohls, J. (2016). Banks and sovereign risk: A granular view. Journal of Financial Stability, 25, 1-15.

Cantero-Saiz, M, Sanfilippo-Azofra, S., Torre-Olmo, B., \& Lopez-Gutierrez, C. (2014). Sovereign risk and the bank lending channel in Europe. Journal of International Money and Finance, 47, 1-20.

Carboni, M., Fiordelisi, F., Ricci, O., \& Lopes, F. S. S. (2017). Surprised or not surprised? The investors' reaction to the comprehensive assessment preceding the launch of the banking union. Journal of Banking and Finance, 74, 122-132.

Carhart, M. (1997). On persistence in mutual fund performance. Journal of Finance, 52, 57-82. 
Caselli, S., Gandolfi, G., \& Soana, M. G. (2014). The impact of sovereign rating news on European banks. European Financial Management, 22(1), 142-167.

CGFS (2011). The impact of sovereign credit risk on bank funding conditions. CGFS Papers, (43).

Correa, R., Lee, K. H., Sapriza, H., \& Suarez, G. A. (2014). Sovereign credit risk, banks' government support, and bank stock returns around the world. Journal of Money, Credit and Banking, 46(1), 93-121.

Correa, R., Sapriza, H, \& Zlate, A. (2012). Liquidity shocks, dollar funding costs, and the bank lending channel during the European sovereign crisis. Federal Reserve System International Finance Discussion Papers, 1059.

Darvas, Z., \& Wolff, G. (2013). Should non-euro area countries join the Single Supervisory Mechanism? Bruegel Policy Contribution, (2013/06).

Davies, M., \& Ng, T. (2011). The rise of sovereign credit risk: Implications for financial stability. BIS Quarterly Review, 59-70.

De Bruyckere, V., Gerhardt, M., Schephens, G., \& Vander Vennet, R. (2013). Bank/sovereign risk spillovers in the European debt crisis. Journal of Banking and Finance, 37, 4793-4809.

Demirgüç-Kunt, A., \& Huizinga, H. (2013). Are banks too big to fail or too big to save? International evidence from equity prices and CDS spreads. Journal of Banking and Finance, 37, 875-894.

Dieckmann, S., \& Plank, T. (2012). Default risk of advanced economies: An empirical analysis of credit default swaps during the financial crisis. Review of Finance, 16, 903-934.

Drago, D., \& Gallo, R. (2016). The impact and the spillover effect of a sovereign rating announcement on the euro area CDS market. Journal of International Money and Finance, 67, 264-286.

Easley, D., O’Hara, M., \& Srinivas, P.S. (1998). Option volume and stock prices: evidence on where informed traders trade. Journal of Finance, 53, 431-465.

Ejsing, J., \& Lemke, W. (2011). The Janus-headed salvation: sovereign and bank credit risk premia during 2008-09. Economic Letters, 110 (1), 28-31.

Engler, P., \& Steffen, C. G. (2016). Sovereign risk, interbank freezes, and aggregate fluctuations. European Economic Review, 87, 34-61.

European Commission (2012). Commission proposes new ECB powers for banking supervision as part of a banking union. Press Release, 12 September 2012.

Fama, E. F., \& French, K. R. (1993). Common risk factors in the returns on stocks and bonds. Journal of Financial Economics, 33, 3-56.

Fontana, A., \& Scheicher, M. (2010). An analysis of euro area sovereign CDS and their relation with government bonds. ECB Working Paper, 1271.

Forbes, K., \& Rigobon, R. (2002). No contagion, only interdependence: Measuring stock market comovements. The Journal of Finance, 57(5), 2223-2261.

Gennaioli, N., Martin, A., \& Rossi, S. (2014). Sovereign default, domestic banks, and financial institutions. The Journal of Finance, 64 (2), 819-866.

Gerlach, S., Schulz, A., \& Wolff, G. B. (2010). Banking and sovereign risk in the euro area. Deutsche Bundesbank Eurosystem. Discussion Paper Series 1: Economic Studies, (09/2010).

Gervais, S., \& Odean, T. (2001). Learning to be overconfident. The Review of Financial Studies, 14, 1-27.

Giannikos, C., Guirguis, H., \& Suen, M. (2013). The 2008 financial crisis and the dynamics of price discovery among stock prices, CDS spreads, and bond spreads for U.S. financial firms. The Journal of Derivatives (Fall), 21 (1), 27-48.

Gray, D.F. \& Malone, S.W. (2012). Sovereign and financial-sector risk: Measurement and interactions. Annual Review of Financial Economics, 4 (1), 297-312.

Gray, D. F., Merton, R. C., \& Bodie, Z. (2008). New framework for measuring and managing macrofinancial risk and financial stability. National Bureau of Economic Research Working Paper (13607).

Gündüz, Y., \& Kaya, O. (2014). Impacts of the financial crisis on eurozone sovereign CDS spreads. Journal of International Money and Finance, 49, 425-442.

Hausman, J. A. (1978). Specification tests in econometrics. Econometrica: Journal of the Econometric Society, 46(6), 1251-1271.

Howarth, D., \& Quaglia, L. (2015). The political economy of the new Single Supervisory Mechanism: Squaring the "Inconsistent Quartet". European Consortium of Political Research, Joint Sessions, 1015.

Hsiao, C. (1985). Benefits and limitations of panel data. Economic Review, 4, 121-174.

Idier, J., Lamé, G., \& Mésonnier, J. S. (2014). How useful is the marginal expected shortfall for the measurement of systemic risk exposure? A practical assessment. Journal of Banking and Finance, $47,134-146$. 
Jegadeesh, N., \& Titman, S. (1993). Returns to buying winners and selling losers: Implications for stock market efficiency. Journal of Finance, 48, 65-91.

Jiang, L., Levine, R., \& Lin, C. (2017). Does competition affect bank risk? National Bureau of Economic Research (No. w23080).

Kallestrup, R., Lando, D., \& Murgoci, A. (2016). Financial sector linkages and the dynamics of bank and sovereign credit spreads. Journal of Empirical Finance, 38, 374-393.

Kräussl, R., Lehnert, T., \& Stefanova, D. (2016). The European sovereign debt crisis: What have we learned? Journal of Empirical Finance, 38, 363-373.

Leblond, P. (2014). The logic of a banking union for Europe. Journal of Banking Regulation, 15 (3/4), 288-298.

Li, J., \& Zinna, G. (2014). How much of bank credit risk is sovereign risk? Evidence from the eurozone. Bank of Italy Working Papers $\mathrm{N}^{\circ} 990$.

Lintner, J. (1965). The valuation of risk assets and the selection of risky investments in stock portfolios and capital budgets. Review of Economics and Statistics, 47, 13-37.

Longstaff, F., Pan, J., Pedersen, L., \& Singleton, K. (2011). How sovereign is sovereign credit risk? American Economic Journal: Macroeconomics, 3(2), 75-103.

McQueen, G., Pinegar, M., \& Thorley, S. (1996). Delayed reaction to good news and the crossautocorrelation of portfolio returns. The Journal of Finance, 51(3), 889-919.

Merler, S., \& Pisani-Ferri, J. (2012). Who's afraid of sovereign bonds? Bruegel Policy Contribution 2012|02, February 2012.

Mody, A. (2009). From Bear Stearns to Anglo Irish: How eurozone sovereign spreads related to financial sector vulnerability. IMF Working Papers, 09/108.

Nowotny, E. (2014). The future of European monetary integration. Atlantic Economic Journal, 42(3), 229-242.

Odean, T. (1998). Are investors reluctant to realize losses? Journal of Finance, 53, 1775-1798.

Pasquariello, P. (2007). Imperfect competition, information heterogeneity, and financial contagion. The Review of Financial Studies, 20(2), 391-426.

Popov, A., \& van Horen, N. (2013). The impact of sovereign debt exposure on bank lending: Evidence from the European debt crisis. DNB Working Paper, (382).

Schich, S., \& Lindh, S. (2012). Implicit guarantees for bank debt: where do we stand? OECD Financial Markets Trends, 2012/1.

Sharpe, W.F. (1964). Capital asset prices: A theory of market equilibrium under conditions of risk. Journal of Finance, 19, 425-442.

Statman, M., Thorley, S., \& Vorkink, K. (2006). Investor overconfidence and trading volume. The Review of Financial Studies, 19, 1535-1565.

Veronesi, P. (1999). Stock market overreaction to bad news in good times: A rational expectations equilibrium model. The Review of Financial Studies, 12(5), 975-1007.

Williams, G., Alsakka, R., \& ap Gwilym, O. (2013). The impact of sovereign rating actions on bank ratings in emerging markets. Journal of Banking and Finance, 37, 563-577.

Yip, P.S.L., \& Tsang, E.W.K. (2007). Interpreting dummy variables and their interaction effects in strategy research. Strategic Organization, 5(1), 13-30.

Yu, S. (2017). Sovereign and bank interdependencies: Evidence from the CDS market. Research in International Business and Finance, 39, 68-84. 


\section{Tables and figures}
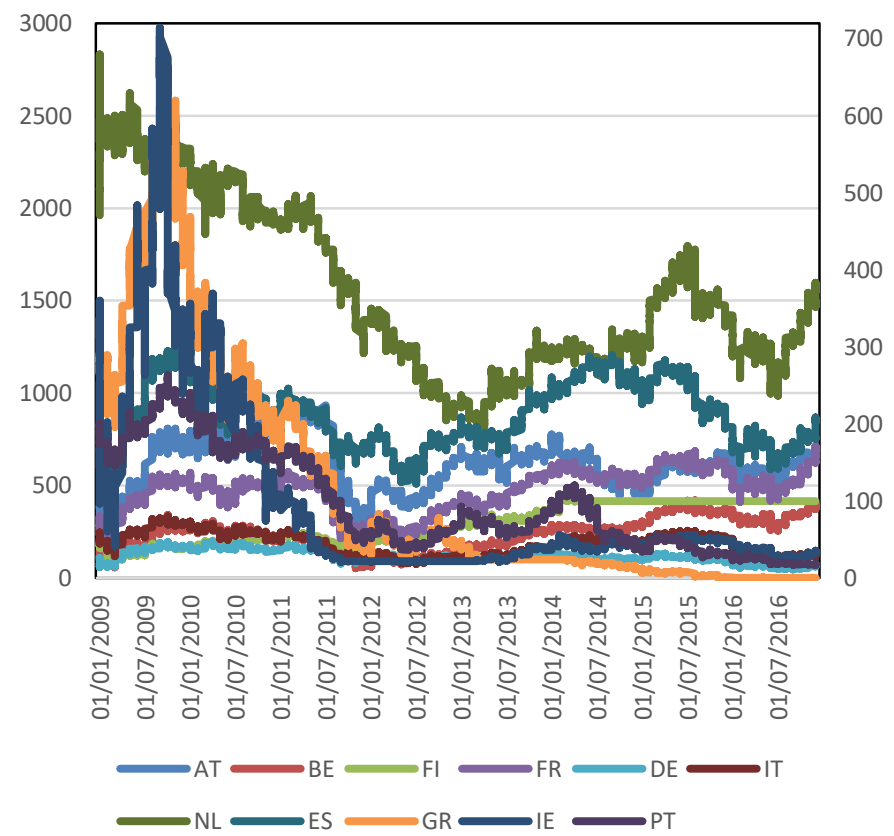

Fig. 1: Stock market's banks index in Eurozone countries. This figure shows the evolution of the stock market's banks index on a daily country-by-country basis between $1^{\text {st }}$ January 2009 and $31^{\text {st }}$ December 2016. The index for Greece, Ireland and Portugal are shown at the right y-axis, whereas the index for all other countries is shown at the left y-axis.

Source: own elaboration based on data from Datastream

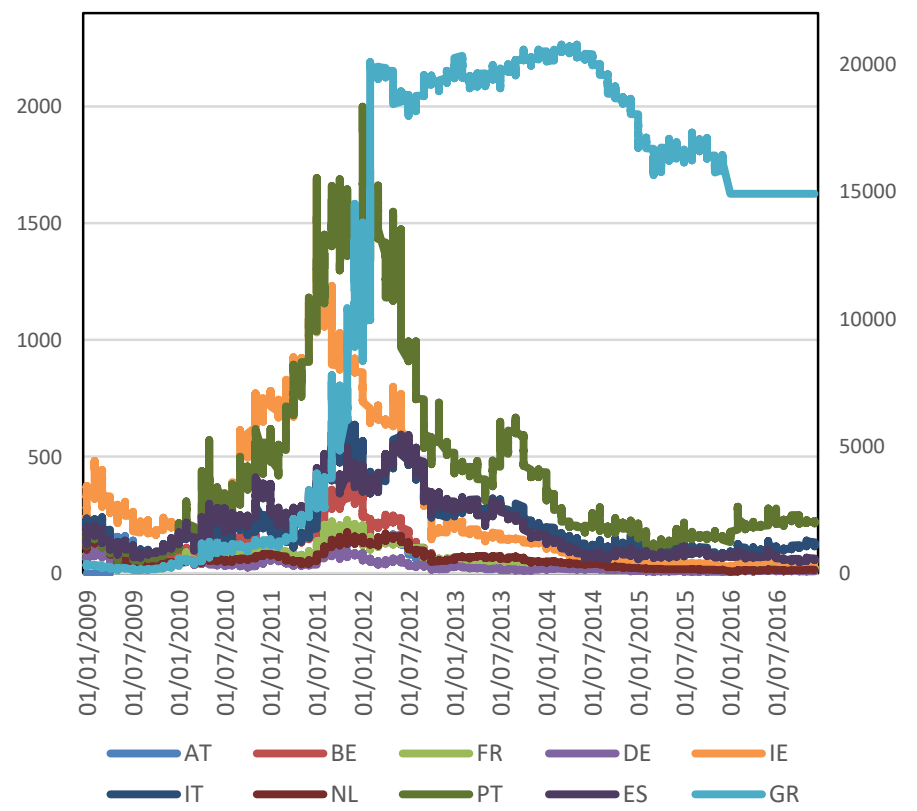

Fig. 3: Sovereign CDS spreads.

This figure shows the evolution of the CDS spread for sovereigns on a daily country-by-country basis between $1^{\text {st }}$ January 2009 and $31^{\text {st }}$ December 2016. The CDS spread for Greece is shown at the right $y$-axis, whereas the spread for all other countries is shown at the left y-axis.

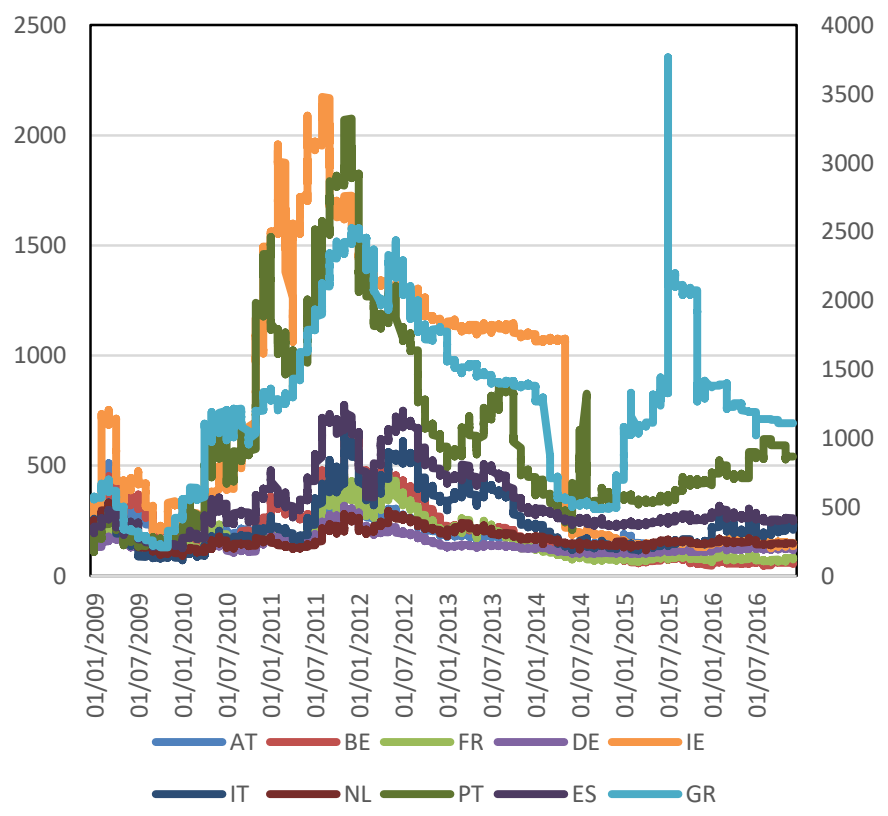

Fig. 2: Bank CDS spreads.

This figure shows the evolution of the average CDS spread for banks on a daily country-by-country basis between $1^{\text {st }}$ January 2009 and $31^{\text {st }}$ December 2016. The CDS spread for Greece is shown at the right y-axis, whereas the spread for all other countries is shown at the left y-axis.

Source: own elaboration based on data from Datastream

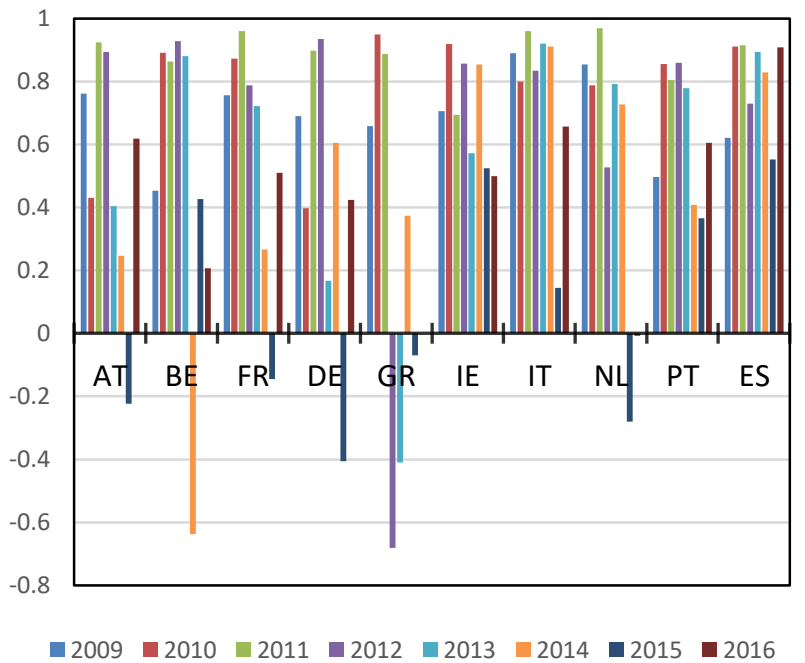

Fig. 4: Bank - Sovereign CDS correlations.

This figure shows the average yearly correlations between the sovereign CDS spread and the banks headquartered in that country between 2009 and 2016.

Source: own elaboration based on data from Datastream 


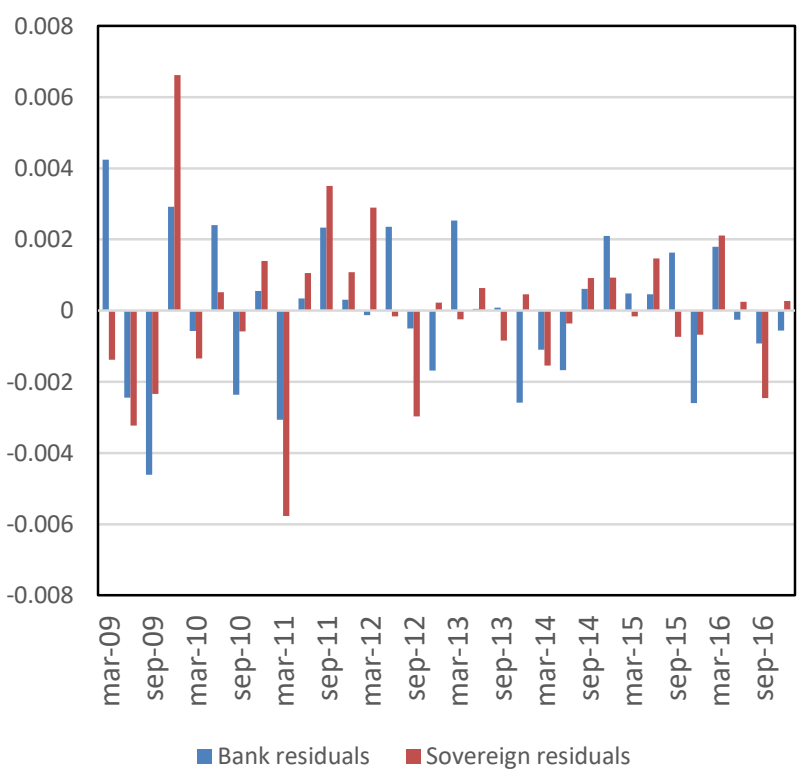

Fig. 5: Quarterly average of bank and sovereign residuals. This figure shows the evolution of the quarterly averages of the banks and sovereigns CDS spreads residuals between January 2009 and December 2016 (Equation (3)).

Source: own elaboration based on data from Datastream

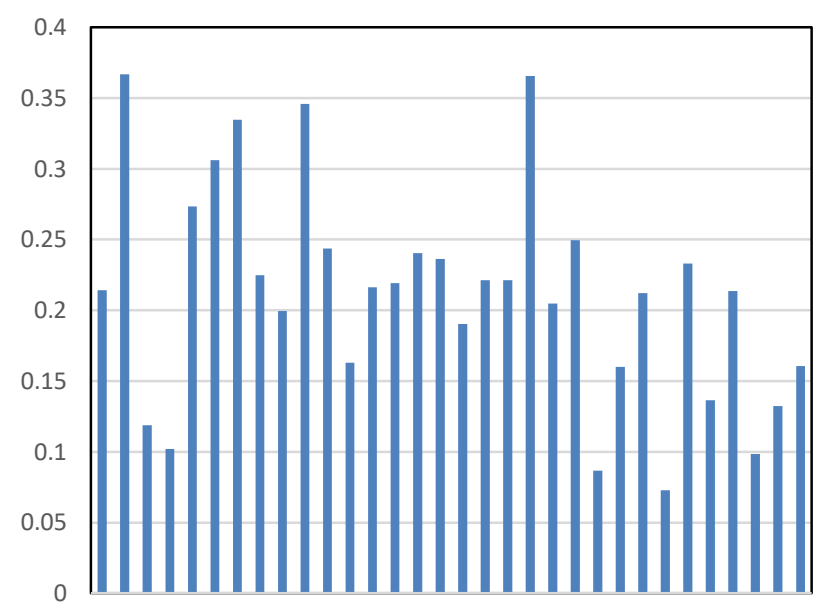

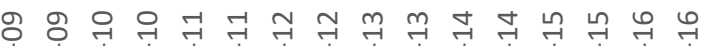
है

Fig. 6: Quarterly average of the correlations between bank and sovereign residuals.

This figure shows the evolution of the quarterly averages of the correlations between the residuals of a bank and those from its respective home country between January 2009 and December 2016 (Equation (3)).

Source: own elaboration based on data from Datastream

Table 1: Stock returns analysis - List of countries and banks

\begin{tabular}{|c|c|}
\hline Austria & $\begin{array}{l}\text { Autobank, Bank für Tirol und Vorarlberg, BKS Bank, Erste Group Bank, Oberbank, } \\
\text { Raiffeisen Bank, and Volksbank. }\end{array}$ \\
\hline Belgium & Banque Nationale de Belgique, Dexia, and KBC Bank. \\
\hline Finland & Aktia, and Alandsbanken. \\
\hline France & $\begin{array}{l}\text { BNP Paribas, Crédit Agricole, CRCAM Alpes Provence, CRCAM Atlantique } \\
\text { Vendée, CRCAM Brie Picardie, CRCAM d'Tlle-de-France, CRCAM d'Ille-et- } \\
\text { Vilaine, CRCAM Languedoc, CRCAM Loire Haute Loire, CRCAM Morbihan, } \\
\text { CRCAM Nord De France, CRCAM Normandie Seine, CRCAM Sud Rhône Alpes, } \\
\text { CRCAM Toulouse 31, CRCAM Touraine, Natixis, and Société Generale. }\end{array}$ \\
\hline Germany & $\begin{array}{l}\text { Commerzbank, Deutsche Bank, Merkur Bank, Oldenburgische Landesbank, Quirin } \\
\text { Bank, Südwestbank, UmweltBank, and WestLB. }\end{array}$ \\
\hline Greece & $\begin{array}{l}\text { Alpha Bank, Attica Bank, Eurobank Ergasias, National Bank of Greece, Piraeus } \\
\text { Bank, T Bank, and TT Hellenic Postbank. }\end{array}$ \\
\hline Ireland & Allied Irish Banks, Bank of Ireland, and Permanent tsb. \\
\hline Italy & $\begin{array}{l}\text { Banca Carige, Banca Finnat Euramerica, Banca Monte dei Paschi, Banca Piccolo } \\
\text { Credito Valtellinese, Banca Popolare dell'Emilia Romagna, Banca Popolare di } \\
\text { Milano, Banca Popolare di Sondrio, Banca Profilo, Banco BPM, Banco di Sardegna, } \\
\text { Banco Desio, Credito Emiliano, Intesa Sanpaolo, Mediobanca, Unicredit, and Unione } \\
\text { di Banche Italiene. }\end{array}$ \\
\hline Lithuania & Siauliu Bankas. \\
\hline Netherlands & ING Groep, and Van Lanschot Kempen. \\
\hline Portugal & $\begin{array}{l}\text { Banco Comercial Português, Banco Espirito Santo, and Banco Português de } \\
\text { Investimento. }\end{array}$ \\
\hline Slovakia & OTP Banka, Tatra Banka, and Úverová Banka. \\
\hline Spain & $\begin{array}{l}\text { Banco Bilbao Vizcaya Argentaria, Banco Popular Español, Banco Sabadell, Banco } \\
\text { Santander, Bankia, Bankinter, Caixabank, and Liberbank. }\end{array}$ \\
\hline
\end{tabular}

This table shows the list of the 80 banks and 13 countries included in our stock returns analysis. For each bank we report its home country. 
Table 2: Stock returns analysis - Summary of the independent variables

\begin{tabular}{|c|c|c|}
\hline Variable & Proxy & $\begin{array}{l}\text { Expected relationship with } \\
\text { banks' stock returns }\end{array}$ \\
\hline SSM & $\begin{array}{l}\text { Entry into force of the SSM. Dummy variable (1: from } \\
\text { Q4-2014 to Q4-2016; } 0 \text { otherwise) }\end{array}$ & NEGATIVE \\
\hline SR & $\left(\mathrm{CDS}_{\text {Sovt }}-\mathrm{CDS}_{\text {Sovt-1 }}\right) / \mathrm{CDS}_{\text {Sovt-1 }}$ & NEGATIVE \\
\hline SSM*SR & Interaction term between the SSM and SR & POSITIVE \\
\hline $\mathrm{R}_{\mathrm{M}, \mathrm{t}}$ & $\begin{array}{l}\text { Difference between the average of the total daily } \\
\text { European returns and the } 10 \text {-year German government } \\
\text { interest rate in quarter } t\end{array}$ & POSITIVE/NEGATIVE \\
\hline RsmB,t & $\begin{array}{l}\text { Spread between the returns on small and big European } \\
\text { stocks }\end{array}$ & POSITIVE/NEGATIVE \\
\hline $\mathrm{R}_{\mathrm{HML}, \mathrm{t}}$ & $\begin{array}{l}\text { Spread between the returns of high book-to-market } \\
\text { European stocks (value stocks) and low ones (growth } \\
\text { stocks) }\end{array}$ & POSITIVE/NEGATIVE \\
\hline RмOM,t & $\begin{array}{l}\text { Spread between the returns of past winners (European } \\
\text { stocks with the highest prior returns) and past losers } \\
\text { (European stocks with the lowest prior returns) }\end{array}$ & POSITIVE/NEGATIVE \\
\hline
\end{tabular}

This table shows the independent variables used in Equation (1) and their expected relationship with the dependent variable ( $\mathrm{R}_{\mathrm{i}, \mathrm{t}}$ : bank's stock returns). SSM represents the Single Supervision Mechanism; SR the sovereign risk; SSM*SR the interaction term between the Single Supervision Mechanism and sovereign risk; $\mathrm{R}_{\mathrm{M}, \mathrm{t}}$ the market risk; $\mathrm{R}_{\mathrm{SMB}, \mathrm{t}}$ the small size risk; $\mathrm{R}_{\mathrm{HML}, \mathrm{t}}$ the distress risk; and $\mathrm{R}_{\mathrm{MOM}, \mathrm{t}}$ the momentum effect.

Table 3: Stock returns analysis - Sample statistics

\begin{tabular}{|c|c|c|c|c|}
\hline Variable & Mean & Standard deviation & Minimum & Maximum \\
\hline $\mathrm{R}_{\mathrm{i}, \mathrm{t}}$ & -4.8988 & 21.8032 & -108.1075 & 225.1063 \\
$\mathrm{SR}$ & 3.3835 & 30.0970 & -53.2569 & 143.2854 \\
$\mathrm{R}_{\mathrm{M}, \mathrm{t}}$ & -0.1329 & 6.0315 & -20.054 & 14.5834 \\
$\mathrm{R}_{\mathrm{SMB}, \mathrm{t}}$ & 0.0017 & 0.3919 & -1.0100 & 0.4850 \\
$\mathrm{R}_{\mathrm{HML}, \mathrm{t}}$ & 0.0418 & 0.2007 & -0.3700 & 0.5050 \\
$\mathrm{R}_{\mathrm{MOM}, \mathrm{t}}$ & 0.0649 & 0.3159 & -0.7550 & 0.6200 \\
\hline
\end{tabular}

This table shows the summary statistics for the continuous variables used in Equation (1). $\mathrm{R}_{\mathrm{i}, \mathrm{t}}$ represents the bank's stock returns; SR the sovereign risk; $\mathrm{R}_{\mathrm{M}, \mathrm{t}}$ the market risk; $\mathrm{R}_{\mathrm{SMB}, \mathrm{t}}$ the small size risk; $\mathrm{R}_{\mathrm{HML}, \mathrm{t}}$ the distress risk; and $\mathrm{R}_{\mathrm{MOM}, \mathrm{t}}$ the momentum effect.

Table 4: Stock returns analysis - Correlations

\begin{tabular}{|c|ccccc|}
\hline & SR & $\mathrm{R}_{\mathrm{M}, \mathrm{t}}$ & $\mathrm{R}_{\mathrm{SMB}, \mathrm{t}}$ & $\mathrm{R}_{\text {HML }, \mathrm{t}}$ & $\mathrm{R}_{\text {MOM }, \mathrm{t}}$ \\
\hline $\mathrm{SR}$ & 1 & & & & \\
$\mathrm{R}_{\mathrm{M}, \mathrm{t}}$ & -0.5585 & 1 & & & \\
$\mathrm{R}_{\mathrm{SMB}, \mathrm{t}}$ & 0.0934 & 0.2000 & 1 & & \\
$\mathrm{R}_{\text {HML }, \mathrm{t}}$ & -0.2018 & 0.2061 & -0.0299 & 1 & \\
$\mathrm{R}_{\text {MOM }, \mathrm{t}}$ & 0.0968 & 0.0558 & 0.3307 & -0.2536 & 1 \\
\hline
\end{tabular}

This table shows the correlations between the continuous independent variables used in Equation (1). SR represents the sovereign risk; $\mathrm{R}_{\mathrm{M}, \mathrm{t}}$ the market risk; $\mathrm{R}_{\mathrm{SMB}, \mathrm{t}}$ the small size risk; $\mathrm{R}_{\mathrm{HML}, \mathrm{t}}$ the distress risk; and $\mathrm{R}_{\mathrm{MOM}, \mathrm{t}}$ the momentum effect. 
Table 5: Stock returns analysis - Results

\begin{tabular}{|c|c|c|c|c|c|c|c|c|}
\hline & $\begin{array}{c}\text { (a) } \\
\text { SSM }\end{array}$ & & $\begin{array}{c}\text { (b) } \\
\text { SSMANN }\end{array}$ & & $\begin{array}{c}(\mathrm{c}) \\
\text { DRAGHI }\end{array}$ & & $\begin{array}{c}(\mathrm{d}) \\
\text { SRM }\end{array}$ & \\
\hline SSM & $-1.7234(-1.92)$ & * & & & & & & \\
\hline SSMANN & & & $0.4877(0.54)$ & & & & & \\
\hline DRAGHI & & & & & $1.8398(1.81)$ & $*$ & & \\
\hline SRM & & & & & & & $-4.0811(-3.30)$ & $* * *$ \\
\hline SR & $-0.1520(-8.91)$ & $* * *$ & $-0.1278(-7.04) *$ & $* * *$ & $-0.1134(-5.63)$ & $* * *$ & $-0.1420(-8.56)$ & $* * *$ \\
\hline SSM*SR & $0.1833(3.11)$ & $* * *$ & & & & & & \\
\hline SSMANN*SR & & & $-0.0480(-1.08)$ & & & & & \\
\hline DRAGHI*SR & & & & & $-0.0342(-0.90)$ & & & \\
\hline SRM*SR & & & & & & & $0.2205(2.71)$ & $* * *$ \\
\hline $\mathrm{R}_{\mathrm{M}, \mathrm{t}}$ & $0.6319(7.61)$ & $* * *$ & $0.6835(8.15)$ & $* * *$ & $0.7040(8.33)$ & $* * *$ & $0.6708(8.13)$ & $* * *$ \\
\hline $\mathrm{R}_{\mathrm{SMB}, \mathrm{t}}$ & $4.9415(4.41)$ & $* * *$ & $4.0001(3.62)$ & $* * *$ & $3.7415(3.37)$ & $* * *$ & $4.5645(4.16)$ & $* * *$ \\
\hline $\mathrm{R}_{\mathrm{HML}, \mathrm{t}}$ & $13.7740(6.67)$ & $* * *$ & $12.8621(6.15) \quad *$ & $* * *$ & $13.4928(6.56)$ & $* * *$ & $13.6288(6.63)$ & $* * *$ \\
\hline $\mathrm{R}_{\mathrm{MOM}, \mathrm{t}}$ & $-1.0990(-0.80)$ & & $-1.2208(-0.83)$ & & $-2.1271(-1.41)$ & & $-0.7164(-0.52)$ & \\
\hline CONS & $-4.3639(-8.88)$ & $* * *$ & $-5.1537(-8.84) *$ & $* * *$ & $-6.0408(-8.41)$ & $* * *$ & $-4.4715(-10.23)$ & $* * *$ \\
\hline LR Test. SSM*SR & $0.0314(0.54)$ & & & & & & & \\
\hline LR Test. SSMANN*SR & & & $-0.1758(-4.10) *$ & $* * *$ & & & & \\
\hline LR Test. DRAGHI*SR & & & & & $-0.1476(-4.04)$ & $* * *$ & & \\
\hline LR Test. SRM $*$ SR & & & & & & & $0.0786(0.96)$ & \\
\hline R-squared (overall) & 0.172 & & 0.167 & & 0.166 & & 0.173 & \\
\hline Hausman test & 0.000 & & 0.000 & & 0.000 & & 0.000 & \\
\hline OLS model & Fixed effects & & Fixed effects & & Fixed effects & & Fixed effects & \\
\hline
\end{tabular}

The dependent variable is bank's stock returns $\left(\mathrm{R}_{\mathrm{i}, \mathrm{t}}\right)$; LR Test. SSM*SR is the linear restriction test of the sum of the coefficients associated with SSM and SR under the following null hypothesis: $\mathrm{H}_{0}: \beta_{2}+\beta_{3}=0$. LR Test. SSMANN*SR is the linear restriction test of the sum of the coefficients associated with SSMANN and SR under the following null hypothesis: $H_{0}: \beta_{2}+\beta_{3}=0$. LR Test. DRAGHI*SR is the linear restriction test of the sum of the coefficients associated with DRAGHI and SR under the following null hypothesis: $H_{0}: \beta_{2}+\beta_{3}=0$. LR Test. SRM*SR is the linear restriction test of the sum of the coefficients associated with SRM and SR under the following null hypothesis: $\mathrm{H}_{0}: \beta_{2}+\beta_{3}=0$. CONS is the regression intercept. R-squared (overall) is the proportion of the variation in bank's stock returns explained by the model. Hausman test is a test of correlation between the unique errors $\left(\mathrm{u}_{\mathrm{i}}\right)$ and the explanatory variables $\left(\mathrm{X}_{\mathrm{i}, \mathrm{t}}\right)$, and serves to determine whether fixed or random effects are suitable. OLS model denotes whether we use fixed or random effects depending on the result of the Hausman test.

First, the results show the coefficients associated with each variable; Second, they show in brackets T-student; Third they depict the level of significance of each variable: *** indicates a level of significance of 0.01 ; ** indicates a level of significance of 0.05 ; and * indicates a level of significance of 0.1 . 
Table 6: Stock returns analysis - Results (Robustness check)

\begin{tabular}{|c|c|c|c|c|c|c|c|c|}
\hline & $\begin{array}{c}\text { (a) } \\
\text { SSM }\end{array}$ & & $\begin{array}{c}\text { (b) } \\
\text { SSMANN }\end{array}$ & & $\begin{array}{c}\text { (c) } \\
\text { DRAGHI }\end{array}$ & & $\begin{array}{c}\text { (d) } \\
\text { SRM }\end{array}$ & \\
\hline SR & $-0.0791(-3.13)$ & $* * *$ & $-0.0532(-2.01)$ & $* *$ & $-0.0693(-2.58)$ & $* *$ & $-0.0777(-3.17)$ & $* * *$ \\
\hline $\mathrm{SSM} * \mathrm{SR}$ & $-0.0129(-0.18)$ & & & & & & & \\
\hline SSMANN * SR & & & $-0.1257(-2.25)$ & $* *$ & & & & \\
\hline DRAGHI $*$ SR & & & & & $-0.0461(-0.89)$ & & & \\
\hline $\mathrm{SRM} * \mathrm{SR}$ & & & & & & & $-0.0449(-0.46)$ & \\
\hline $\mathrm{R}_{\mathrm{M}, \mathrm{t}}$ & $0.6768(5.21)$ & $* * *$ & $0.1044(0.57)$ & & $0.0436(0.24)$ & & $0.6814(5.32)$ & $* * *$ \\
\hline $\mathrm{R}_{\mathrm{SMB}, \mathrm{t}}$ & $1.1906(0.50)$ & & $24.9121(10.70)$ & $* * *$ & $24.7121(10.62) *$ & $* * *$ & $1.1625(0.49)$ & \\
\hline RнML,t & $50.9588(7.62)$ & $* * *$ & $27.2619(7.71)$ & $* * *$ & $27.2869(7.71)$ & $* * *$ & $51.0418(7.65)$ & $* * *$ \\
\hline $\mathrm{R}_{\mathrm{MOM}, \mathrm{t}}$ & $-7.7954(-3.36)$ & $* * *$ & $-1.6397(-0.52)$ & & $-0.1387(-0.04)$ & & $-7.8435(-3.40)$ & $* * *$ \\
\hline CONS & $-10.3173(-5.96)$ & $* * *$ & $4.4010(3.30)$ & *** & $4.8798(3.66)$ & $* * *$ & $-10.3540(-6.01)$ & $* * *$ \\
\hline LR Test. SSM*SR & $-0.0919(-1.42)$ & & & & & & & \\
\hline LR Test. SSMANN*SR & & & $-0.1789(-3.62)$ & $* * *$ & & & & \\
\hline LR Test. DRAGHI*SR & & & & & $-0.1154(-2.54)$ & $* *$ & & \\
\hline LR Test. SRM*SR & & & & & & & $-0.1226(-1.31)$ & \\
\hline Time dummies & Yes & & Yes & & Yes & & Yes & \\
\hline R-squared (overall) & 0.272 & & 0.271 & & 0.272 & & 0.272 & \\
\hline Hausman test & 0.000 & & 0.000 & & 0.000 & & 0.000 & \\
\hline OLS model & Fixed effects & & Fixed effects & & Fixed effects & & Fixed effects & \\
\hline
\end{tabular}

The dependent variable is bank's stock returns $\left(\mathrm{R}_{\mathrm{i}, t}\right)$; LR Test. SSM*SR is the linear restriction test of the sum of the coefficients associated with SSM and SR under the following null hypothesis: $\mathrm{H}_{0}: \beta_{2}+\beta_{3}=0$. LR Test. SSMANN*SR is the linear restriction test of the sum of the coefficients associated with SSMANN and SR under the following null hypothesis: $\mathrm{H}_{0}: \beta_{2}+\beta_{3}=0$. LR Test. DRAGHI*SR is the linear restriction test of the sum of the coefficients associated with DRAGHI and SR under the following null hypothesis: $\mathrm{H}_{0}: \beta_{2}+\beta_{3}=0$. LR Test. SRM $*$ SR is the linear restriction test of the sum of the coefficients associated with SRM and SR under the following null hypothesis: $\mathrm{H}_{0}: \beta_{2}+\beta_{3}=0$. Time dummies are included in the estimations, but no reported. CONS is the regression intercept. R-squared (overall) is the proportion of the variation in bank's stock returns explained by the model. Hausman test is a test of correlation between the unique errors $\left(\mathrm{u}_{\mathrm{i}}\right)$ and the explanatory variables $\left(\mathrm{X}_{\mathrm{i}, t}\right)$, and serves to determine whether fixed or random effects are suitable. OLS model denotes whether we use fixed or random effects depending on the result of the Hausman test. First, the results show the coefficients associated with each variable; Second, they show in brackets T-student; Third they depict the level of significance of each variable: *** indicates a level of significance of 0.01 ; ** indicates a level of significance of 0.05 ; and * indicates a level of significance of 0.1 .

Table 7: CDS spreads analysis - List of countries and banks

\begin{tabular}{|l|l|}
\hline Austria & Erste Group Bank, and Raiffeisen Bank. \\
\hline Belgium & KBC Bank. \\
\hline France & BNP Paribas, Crédit Agricole, Natixis, and Société Generale. \\
\hline Germany & Commerzbank, and Deutsche Bank. \\
\hline Greece & Alpha Bank, Eurobank Ergasias, and National Bank of Greece. \\
\hline Ireland & Allied Irish Banks. \\
\hline Italy & $\begin{array}{l}\text { Banca Monte dei Paschi, Intesa Sanpaolo, Mediobanca, Unicredit, and Unione di } \\
\text { Banche Italiene. }\end{array}$ \\
\hline Netherlands & ING Groep. \\
\hline Portugal & Banco Comercial Português. \\
\hline Spain & $\begin{array}{l}\text { Banco Bilbao Vizcaya Argentaria, Banco Popular Español, Banco Sabadell, Banco } \\
\text { Santander, and Bankinter. }\end{array}$ \\
\hline
\end{tabular}

This table shows the list of the 25 banks and 10 countries included in our CDS spreads analysis. For each bank we report its home country. 
Table 8: CDS spreads analysis - Summary of the independent variables

\begin{tabular}{|c|c|c|}
\hline Variable & Proxy & $\begin{array}{l}\text { Expected relationship with the } \\
\text { excess correlation (contagion) }\end{array}$ \\
\hline SSM & $\begin{array}{l}\text { Entry into force of the SSM. Dummy variable (1: from } \\
\text { Q4-2014 to Q4-2016; } 0 \text { otherwise) }\end{array}$ & NEGATIVE \\
\hline$\Delta \mathrm{CDS}_{\text {Bank }}$ & $\left(\mathrm{CDS}_{\text {Bankt-CDS }} \mathrm{CDankt-1}_{1}\right) / \mathrm{CDS}_{\text {Bankt-1 }}$ & POSITIVE \\
\hline$\Delta \mathrm{CDS}_{\mathrm{Sov}}$ & $\left(\mathrm{CDS}_{\text {Sovt }}-\mathrm{CDS}_{\text {Sovt-1 }}\right) / \mathrm{CDS}_{\text {Sovt-1 }}$ & POSITIVE \\
\hline $\mathrm{SSM}^{*} \Delta \mathrm{CDS}_{\mathrm{Bank}}$ & $\begin{array}{c}\text { Interaction term between the SSM and bank CDS } \\
\text { growth }\end{array}$ & NEGATIVE \\
\hline $\mathrm{SSM}^{*} \Delta \mathrm{CDSSov}_{\mathrm{S}}$ & $\begin{array}{l}\text { Interaction term between the SSM and sovereign CDS } \\
\text { growth }\end{array}$ & NEGATIVE \\
\hline SIZE & Bank's total assets/ Home country GDP & POSITIVE \\
\hline CAP & Risk-weighted Tier 1 capital ratio & NEGATIVE \\
\hline RETAIL & Loans/Assets & NEGATIVE \\
\hline FUNDSTRUC & Short-term market debt/ (Liabilities + Equity) & POSITIVE \\
\hline MES & $\begin{array}{l}\text { Average return of each bank during the } 5 \% \text { worst days } \\
\text { for the European market in quarter } t\end{array}$ & POSITIVE \\
\hline$\Delta \mathrm{GDP}$ & $\left(\mathrm{GDP}_{\left.\mathrm{t}-\mathrm{GDP}_{\mathrm{t}-1}\right) / \mathrm{GDP}_{\mathrm{t}-1}}\right.$ & POSITIVE/ NEGATIVE \\
\hline PUBDEBT & Public debt/GDP & POSITIVE \\
\hline FISCBAL & (Government revenues - expenses)/GDP & NEGATIVE \\
\hline
\end{tabular}

This table shows the independent variables used in Equation (4) and their expected relationship with the dependent variable (EXCCORR: excess correlation between the CDS spreads of a bank and its home country). SSM represents the Single Supervision Mechanism; $\Delta \mathrm{CDS}_{\text {Bank }}$ the bank CDS spread variation; $\triangle \mathrm{CDS}_{\text {Sov }}$ the sovereign $\mathrm{CDS}$ spread variation; $\mathrm{SSM}^{*} \Delta \mathrm{CDS}_{\text {Bank }}$ the interaction term between the Single Supervision Mechanism and the bank CDS spread variation; $\mathrm{SSM}^{*} \Delta \mathrm{CDS}_{\text {Sov }}$ the interaction term between the Single Supervision Mechanism and the sovereign CDS spread variation; SIZE the ratio of each bank's total assets to its home country GDP; CAP the risk-weighted Tier 1 capital ratio; RETAIL the bank's retail orientation; FUNDSTRUC the bank's funding structure; MES the bank's marginal expected shortfall; $\triangle$ GDP the GDP growth; PUBDEBT the ratio of public debt over GDP; and FISCBAL the fiscal balance of a country.

Table 9: Sample statistics

\begin{tabular}{|c|c|c|c|c|}
\hline Variable & Mean & Standard deviation & Minimum & Maximum \\
\hline EXCCORR & 0.2111 & 0.2087 & -0.5977 & 0.9854 \\
$\Delta$ CDS $_{\text {Bank }}$ & 0.0334 & 0.2869 & -0.8255 & 2.3413 \\
$\Delta$ CDSSov $_{\text {SIZE }}$ & 0.0334 & 0.3234 & -0.5488 & 1.6703 \\
CAP & 2.3193 & 1.6875 & 0.1583 & 9.0819 \\
RETAIL & 11.6976 & 2.8093 & -6.7000 & 17.9000 \\
FUNDSTRUC & 0.5868 & 0.1544 & 0.2044 & 0.8253 \\
MES & 0.1821 & 0.0961 & 0.0184 & 0.4646 \\
$\Delta$ GDP & -0.0304 & 0.0264 & -0.1944 & 0.1703 \\
PUBDEBT & 0.0005 & 0.0125 & -0.0474 & 0.2158 \\
FISCBAL & 1.0338 & 0.3068 & 0.4278 & 1.8095 \\
\hline
\end{tabular}

This table shows the summary statistics for the continuous variables used in Equation (4). EXCCORR represents the excess correlation between the CDS spreads of the bank and its home country; $\triangle \mathrm{CDS}_{\text {Bank }}$ the bank CDS spread variation; $\triangle \mathrm{CDS}_{\text {Sov }}$ the sovereign CDS spread variation; SIZE the ratio of each bank's total assets to its home country GDP; CAP the risk-weighted Tier 1 capital ratio; RETAIL the bank's retail orientation; FUNDSTRUC the bank's funding structure; MES the bank's marginal expected shortfall; $\triangle$ GDP the GDP growth; PUBDEBT the ratio of public debt over GDP; and FISCBAL the fiscal balance of a country. The statistics of the variables SIZE, CAP, RETAIL, FUNDSTRUC, MES, $\triangle$ GDP, PUBDEBT and FISCBAL are calculated before the standardization to show more comprehensive information. 
Table 10: Correlations

\begin{tabular}{|c|c|c|c|c|c|c|c|c|c|c|}
\hline & $\Delta \mathrm{CDS}_{\text {Bank }}$ & $\Delta \mathrm{CDS}_{\mathrm{Sov}}$ & SIZE & CAP & RETAIL & FUNDSTRUC & MES & $\Delta \mathrm{GDP}$ & PUBDEBT & FISCBAL \\
\hline$\Delta \mathrm{CDS}_{\text {Bank }}$ & 1 & & & & & & & & & \\
\hline$\Delta \mathrm{CDS}_{\mathrm{Sov}}$ & 0.6340 & 1 & & & & & & & & \\
\hline SIZE & -0.0145 & 0.0016 & 1 & & & & & & & \\
\hline CAP & -0.1299 & -0.2505 & 0.1122 & 1 & & & & & & \\
\hline RETAIL & 0.0578 & 0.0953 & -0.3427 & -0.2144 & 1 & & & & & \\
\hline FUNDSTRUC & 0.0826 & 0.1512 & -0.3371 & -0.1728 & 0.2616 & 1 & & & & \\
\hline MES & -0.2406 & -0.2439 & -0.0272 & 0.0043 & 0.0842 & 0.0838 & 1 & & & \\
\hline$\Delta \mathrm{GDP}$ & -0.1473 & -0.2365 & 0.0503 & 0.2289 & -0.1408 & -0.1965 & 0.1159 & 1 & & \\
\hline PUBDEBT & -0.0068 & 0.0354 & -0.2239 & 0.0948 & 0.2532 & 0.3139 & 0.0179 & -0.1490 & 1 & \\
\hline FISCBAL & -0.1392 & -0.2342 & -0.1074 & 0.2948 & -0.3296 & -0.4439 & $\begin{array}{c}- \\
0.0988\end{array}$ & 0.2012 & -0.0477 & 1 \\
\hline
\end{tabular}

This table shows the correlations between the continuous independent variables used in Equation (4). $\Delta$ CDS $_{\text {Bank }}$ represents the bank CDS spread variation; $\triangle \mathrm{CDS}_{\text {Sov }}$ the sovereign CDS spread variation; SIZE the ratio of each bank's total assets to its home country GDP; CAP the risk-weighted Tier 1 capital ratio; RETAIL the bank's retail orientation; FUNDSTRUC the bank's funding structure; MES the bank's marginal expected shortfall; $\triangle$ GDP the GDP growth; PUBDEBT the ratio of public debt over GDP; and FISCBAL the fiscal balance of a country. 
Table 11: CDS spreads analysis - Results

\begin{tabular}{|c|c|c|c|c|c|}
\hline & $\begin{array}{c}\text { (a) } \\
\text { SSM }\end{array}$ & $\begin{array}{c}\text { (b) } \\
\text { SSMANN }\end{array}$ & $\begin{array}{c}(\mathrm{c}) \\
\text { DRAGHI }\end{array}$ & $\begin{array}{c}\text { (d) } \\
\text { SRM }\end{array}$ & \\
\hline SSM & $-0.0730(-3.27) * * *$ & & & & \\
\hline SSMANN & & $-0.0461(-2.06) * *$ & & & \\
\hline DRAGHI & & & $-0.0459(-2.24) * *$ & & \\
\hline SRM & & & & $-0.0284(-1.11)$ & \\
\hline$\Delta \mathrm{CDS}_{\text {Bank }}$ & $0.0723(1.73) *$ & $0.0855(1.96) *$ & $0.0859(1.83) *$ & $0.0560(1.65)$ & $*$ \\
\hline$\Delta \mathrm{CDS}_{\mathrm{Sov}}$ & $-0.0438(-1.26)$ & $-0.0446(-1.23)$ & $-0.0552(-1.46)$ & $-0.0428(-1.38)$ & \\
\hline $\mathrm{SSM}^{*} \Delta \mathrm{CDS}_{\text {Bank }}$ & $-0.0029(-0.04)$ & & & & \\
\hline $\mathrm{SSM}^{*} \Delta \mathrm{CDS}_{\mathrm{Sov}}$ & $-0.0796(-0.75)$ & & & & \\
\hline $\mathrm{SSMANN}^{*} \Delta \mathrm{CDS}_{\text {Bank }}$ & & $-0.0796(-1.24)$ & & & \\
\hline $\mathrm{SSMANN}^{*} \Delta \mathrm{CDSS}_{\mathrm{Sov}}$ & & $-0.1731(-2.10) * *$ & & & \\
\hline $\mathrm{DRAGHI}^{*} \Delta \mathrm{CDS}_{\text {Bank }}$ & & & $-0.0706(-1.10)$ & & \\
\hline $\mathrm{DRAGHI}^{*} \Delta \mathrm{CDS}_{\mathrm{Sov}}$ & & & $-0.1144(-1.58)$ & & \\
\hline $\mathrm{SRM}^{*} \Delta \mathrm{CDS}_{\text {Bank }}$ & & & & $-0.0171(-0.14)$ & \\
\hline $\mathrm{SRM}^{*} \Delta \mathrm{CDS}_{\mathrm{Sov}}$ & & & & $-0.1297(-0.70)$ & \\
\hline SIZE & $0.0134(0.43)$ & $0.0359(1.25)$ & $0.0174(1.27)$ & 0.0477 (1.64) & \\
\hline CAP & $0.0026(0.27)$ & $0.0040(0.40)$ & $-0.0005(-0.06)$ & $0.0019(0.19)$ & \\
\hline RETAIL & $-0.0093(-0.31)$ & $-0.0055(-0.19)$ & $-0.0098(-0.68)$ & $0.0042(0.14)$ & \\
\hline FUNDSTRUC & $-0.0110(-0.77)$ & $-0.0100(-0.71)$ & $-0.0086(-0.72)$ & $-0.0117(-0.82)$ & \\
\hline MES & $0.0015(0.20)$ & $0.0025(0.33)$ & $0.0015(0.20)$ & $0.0006(0.08)$ & \\
\hline$\Delta \mathrm{GDP}$ & $-0.0006(-0.05)$ & $-0.0020(-0.19)$ & $-0.0025(-0.25)$ & $-0.0038(-0.37)$ & \\
\hline PUBDEBT & $0.0092(0.46)$ & $0.0080(0.36)$ & $0.0067(0.52)$ & $-0.0068(-0.35)$ & \\
\hline FISCBAL & $-0.0138(-0.88)$ & $-0.0169(-1.08)$ & $-0.0199(-1.47)$ & $-0.0208(-1.34)$ & \\
\hline CONS & $0.2291(23.93) * * *$ & $0.2250(18.72) * * *$ & $0.2270(12.41) * * *$ & $0.2148(25.66)$ & $* * *$ \\
\hline LR Test. SSM $* \Delta \mathrm{CDS}_{\text {Bank }}$ & $0.0694(1.28)$ & & & & \\
\hline LR Test. SSM $* \Delta$ CDS $_{\text {Sov }}$ & $-0.1234(-1.22)$ & & & & \\
\hline LR Test. SSMANN* $\Delta$ CDS $_{\text {Bank }}$ & & $0.0090(0.20)$ & & & \\
\hline LR Test. SSMANN* ${ }^{*} \mathrm{CDSS}_{\text {Sov }}$ & & $-0.2177(-2.90) * * *$ & & & \\
\hline LR Test. DRAGHI* $\Delta$ CDS $_{\text {Bank }}$ & & & $0.0153(0.35)$ & & \\
\hline LR Test. DRAGHI* $\triangle \mathrm{CDS}_{\mathrm{Sov}}$ & & & $-0.1696(-2.70) * * *$ & & \\
\hline LR Test. SRM* $\Delta \mathrm{CDS}_{\text {Bank }}$ & & & & $0.0388(0.34)$ & \\
\hline LR Test. SRM $* \Delta$ CDSSov $_{\text {Sov }}$ & & & & $-0.1725(-0.95)$ & \\
\hline $\mathrm{R}^{2}$ (overall) & 0.044 & 0.043 & 0.045 & 0.027 & \\
\hline Hausman test & 0.003 & 0.010 & 0.090 & 0.019 & \\
\hline OLS model & Fixed effects & Fixed effects & Random effects & Fixed effects & \\
\hline
\end{tabular}

The dependent variable is excess correlation between the CDS spreads of the bank and its home country (EXCCORR); LR Test. SSM* $\Delta$ CDS ${ }_{\text {Bank }}$ is the linear restriction test of the sum of the coefficients associated with SSM and $\Delta \mathrm{CDS}_{\text {Bank }}$ under the following null hypothesis: $\mathrm{H}_{0}: \beta_{2}+\beta_{3}=0$. LR Test. $\mathrm{SSM}^{*} \Delta \mathrm{CDS}_{\mathrm{Sov}}$ is the linear restriction test of the sum of the coefficients associated with SSM and $\Delta \mathrm{CDS}_{\text {Sov }}$ under the following null hypothesis: $\mathrm{H}_{0}$ : $\beta_{4}$ $+\beta_{5}=0$. LR Test. SSMANN* ${ }^{*}$ CDS $_{\text {Bank }}$ is the linear restriction test of the sum of the coefficients associated with SSMANN and $\Delta C D S$ Bank under the following null hypothesis: $\mathrm{H}_{0}: \beta_{2}+\beta_{3}=0$. LR Test. SSMANN* ${ }^{*} \mathrm{CDS}_{\mathrm{Sov}}$ is the linear restriction test of the sum of the coefficients associated with SSMANN and $\triangle$ CDS $_{\text {Sov }}$ under the following null hypothesis: $\mathrm{H}_{0}: \beta_{4}+\beta_{5}=0$. LR Test. DRAGHI* $\triangle \mathrm{CDS}$ Bank is the linear restriction test of the sum of the coefficients associated with DRAGHI and $\Delta \mathrm{CDS}_{\mathrm{B} \text { ank }}$ under the following null hypothesis: $\mathrm{H}_{0}: \beta_{2}+\beta_{3}=0$. LR Test. DRAGHI* $\Delta$ CDS

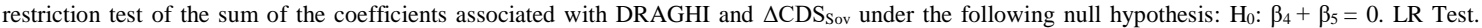
$\mathrm{SRM}^{*} \Delta \mathrm{CDS}_{\text {Bank }}$ is the linear restriction test of the sum of the coefficients associated with SRM and $\Delta \mathrm{CDS}_{\text {Bank }}$ under the following null hypothesis: $\mathrm{H}_{0}$ : $\beta_{2}+\beta_{3}=0$. LR Test. SRM $* \Delta$ CDS $_{\text {Sov }}$ is the linear restriction test of the sum of the coefficients associated with SRM and $\Delta C D S$ Sov under the following null hypothesis: $\mathrm{H}_{0}: \beta_{4}+\beta_{5}=0$. CONS is the regression intercept. R-squared (overall) is the proportion of the variation in excess correlation explained by the model. Hausman test is a test of correlation between the unique errors $\left(\mathrm{u}_{\mathrm{i}}\right)$ and the explanatory variables $\left(\mathrm{X}_{\mathrm{i}, t}\right)$, and serves to determine whether fixed or random effects are suitable. OLS model denotes whether we use fixed or random effects depending on the result of the Hausman test.

First, the results show the coefficients associated with each variable; Second, they show in brackets T-student; Third they depict the level of significance of each variable: *** indicates a level of significance of 0.01 ;** indicates a level of significance of 0.05 ; and * indicates a level of significance of 0.1 . 
Table 12: CDS spreads analysis - Results (Robustness check)

\begin{tabular}{|c|c|c|c|c|}
\hline & $\begin{array}{c}\text { (a) } \\
\text { SSM }\end{array}$ & $\begin{array}{c}\text { (b) } \\
\text { SSMANN }\end{array}$ & $\begin{array}{c}\text { (c) } \\
\text { DRAGHI }\end{array}$ & $\begin{array}{c}\text { (d) } \\
\text { SRM }\end{array}$ \\
\hline$\Delta \mathrm{CDS}_{\text {Bank }}$ & $0.0679(1.33)$ & $0.0666(1.22)$ & $0.0424(0.75)$ & $0.0558(1.40)$ \\
\hline$\Delta \mathrm{CDSSov}_{\mathrm{S}}$ & $-0.0176(-0.40)$ & $0.0049(0.11)$ & $-0.0044(-0.09)$ & $-0.0216(-0.53)$ \\
\hline $\mathrm{SSM}^{*} \mathrm{CCDS}_{\text {Bank }}$ & $-0.0587(-0.77)$ & & & \\
\hline $\mathrm{SSM}^{*} \Delta \mathrm{CDS}_{\mathrm{Sov}}$ & $-0.1524(-1.20)$ & & & \\
\hline $\operatorname{SSMANN}^{*} \Delta \mathrm{CDS}_{\text {Bank }}$ & & $-0.0480(-0.63)$ & & \\
\hline $\operatorname{SSMANN}^{*} \Delta \mathrm{CDS}_{\mathrm{Sov}}$ & & $-0.1839(-1.93) *$ & & \\
\hline DRAGHI $^{*} \Delta \mathrm{CDS}_{\text {Bank }}$ & & & $-0.0037(-0.05)$ & \\
\hline DRAGHI $^{*} \Delta \mathrm{CDSS}_{\mathrm{Sov}}$ & & & $-0.0881(-1.01)$ & \\
\hline $\mathrm{SRM}^{*} \Delta \mathrm{CDS}_{\text {Bank }}$ & & & & $-0.1248(-0.92)$ \\
\hline $\mathrm{SRM}^{*} \Delta \mathrm{CDS}_{\mathrm{Sov}}$ & & & & $-0.1280(-0.64)$ \\
\hline SIZE & $0.0129(0.93)$ & $0.0132(0.97)$ & $0.0134(0.91)$ & $0.0120(0.88)$ \\
\hline CAP & $0.0019(0.21)$ & $0.0029(0.32)$ & $0.0016(0.18)$ & $-0.0001(-0.01)$ \\
\hline RETAIL & $-0.0105(-0.74)$ & $-0.0109(-0.77)$ & $-0.0103(-0.67)$ & $-0.0104(-0.74)$ \\
\hline FUNDSTRUC & $-0.0118(-1.02)$ & $-0.0118(-1.03)$ & $-0.0121(-1.02)$ & $-0.0127(-1.11)$ \\
\hline MES & $0.0009(0.10)$ & $0.0012(0.14)$ & $0.0013(0.14)$ & $0.0011(0.13)$ \\
\hline$\Delta \mathrm{GDP}$ & $-0.0024(-0.22)$ & $-0.0020(-0.18)$ & $-0.0020(-0.18)$ & $-0.0018(-0.16)$ \\
\hline PUBDEBT & $0.0107(0.80)$ & $0.0099(0.75)$ & $0.0110(0.78)$ & $0.0083(0.63)$ \\
\hline FISCBAL & $-0.0065(-0.45)$ & $-0.0071(-0.50)$ & $-0.0071(-0.49)$ & $-0.0087(-0.62)$ \\
\hline CONS & $0.1681(4.08) \quad * * *$ & $0.1683(4.10) \quad * * *$ & $0.1661(3.99) \quad * * *$ & $0.1712(4.15) \quad * * *$ \\
\hline LR Test. SSM $* \Delta$ CDS $_{\text {Bank }}$ & $0.0092(0.16)$ & & & \\
\hline LR Test. SSM $* \Delta \mathrm{CDS}_{\mathrm{Sov}}$ & $-0.1700(-1.43)$ & & & \\
\hline LR Test. SSMANN $* \Delta$ CDS $_{\text {Bank }}$ & & $0.0185(0.35)$ & & \\
\hline LR Test. SSMANN $* \Delta$ CDSSov $_{S}$ & & $-0.1790(-2.12) * *$ & & \\
\hline LR Test. DRAGHI* $\Delta$ CDS $_{\text {Bank }}$ & & & & \\
\hline LR Test. DRAGHI ${ }^{*} \Delta \mathrm{CDSSov}_{\mathrm{Sov}}$ & & & & \\
\hline LR Test. SRM $* \Delta$ CDS $_{\text {Bank }}$ & & & $0.0387(0.76)$ & $-0.0690(-0.53)$ \\
\hline LR Test. SRM $* \Delta$ CDSSov $_{\text {Sov }}$ & & & $-0.0925(-1.21)$ & $-0.1496(-0.77)$ \\
\hline Time dummies & Yes & Yes & Yes & Yes \\
\hline $\mathrm{R}^{2}$ (overall) & 0.146 & 0.151 & 0.146 & 0.146 \\
\hline Hausman test & 0.085 & 0.103 & 0.378 & 0.143 \\
\hline OLS model & Random effects & Random effects & Random effects & Random effects \\
\hline
\end{tabular}

The dependent variable is excess correlation between the CDS spreads of the bank and its home country (EXCCORR); LR Test. SSM* $\Delta$ CDS ${ }_{\text {Bank }}$ is the linear restriction test of the sum of the coefficients associated with SSM and $\Delta$ CDS $_{\text {Bank }}$ under the following null hypothesis: $\mathrm{H}_{0}: \beta_{2}+\beta_{3}=0$. LR Test. $\mathrm{SSM}^{*} \Delta \mathrm{CDS}_{\mathrm{Sov}}$ is the linear restriction test of the sum of the coefficients associated with SSM and $\Delta \mathrm{CDS}_{\mathrm{Sov}}$ under the following null hypothesis: $\mathrm{H}_{0}$ : $\beta_{4}$ $+\beta_{5}=0$. LR Test. SSMANN ${ }^{*} \Delta \mathrm{CDS}_{\text {Bank }}$ is the linear restriction test of the sum of the coefficients associated with SSMANN and $\Delta$ CDS $_{\text {Bank }}$ under the following null hypothesis: $\mathrm{H}_{0}: \beta_{2}+\beta_{3}=0$. LR Test. SSMANN* ${ }^{*} \mathrm{CDS}_{\mathrm{sov}}$ is the linear restriction test of the sum of the coefficients associated with SSMANN and $\triangle C_{\text {CDS }}$ under the following null hypothesis: $\mathrm{H}_{0}: \beta_{4}+\beta_{5}=0$. LR Test. DRAGHI* $\triangle$ CDS Bank $_{\text {is }}$ the linear restriction test of the sum of the

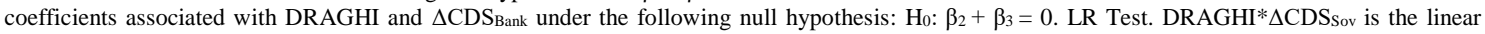
restriction test of the sum of the coefficients associated with DRAGHI and $\Delta$ CDSsov under the following null hypothesis: $\mathrm{H}_{0}: \beta_{4}+\beta_{5}=0$. LR Test. $\mathrm{SRM}^{*} \Delta \mathrm{CDS}_{\mathrm{Bank}}$ is the linear restriction test of the sum of the coefficients associated with SRM and $\Delta \mathrm{CDS}_{\text {Bank }}$ under the following null hypothesis: $\mathrm{H}_{0}$ : $\beta_{2}+\beta_{3}=0$. LR Test. SRM ${ }^{*} \Delta$ CDSSov $_{\text {so }}$ is the linear restriction test of the sum of the coefficients associated with SRM and $\Delta C D S$ sov under the following null hypothesis: $\mathrm{H}_{0}: \beta_{4}+\beta_{5}=0$. Time dummies are included in the estimations, but no reported. CONS is the regression intercept. R-squared (overall) is the proportion of the variation in excess correlation explained by the model. Hausman test is a test of correlation between the unique errors $\left(\mathrm{u}_{\mathrm{i}}\right)$ and the explanatory variables $\left(\mathrm{X}_{\mathrm{i}, \mathrm{t}}\right)$, and serves to determine whether fixed or random effects are suitable. OLS model denotes whether we use fixed or random effects depending on the result of the Hausman test.

First, the results show the coefficients associated with each variable; Second, they show in brackets T-student; Third they depict the level of significance of each variable: $* * *$ indicates a level of significance of $0.01 ; * *$ indicates a level of significance of 0.05 ; and $*$ indicates a level of significance of 0.1 . 